\title{
The Decline of Apprenticeship in North America: Evidence from Montreal
}

\author{
September 1999 \\ Gillian Hamilton ${ }^{*}$ \\ Department of Economics \\ University of Toronto \\ 150 St. George St. \\ Toronto, ON, M5S 3G7 \\ HAMILTNG@chass.utoronto.ca \\ (416) 978-3070
}

\footnotetext{
* I am very grateful for the excellent research assistance of Michel Guénette and the late Sophie Toupin who spent several years collecting most of the data in Montreal, and Sean Clarke who assisted with data coding this past year. Ron Bianchi, Sae Wha Lee, Daryl Maraj, Ataollah Mazaheri, and Yves Otis also provided research assistance. I also thank the Montreal History Group for making accessible their coded forms for contracts signed in the 1820s. Seminar participants at UCLA, UC-Davis, University of Toronto, University of Michigan, Australian National University, the Canadian Economic History meetings (1997) provided helpful comments. I also thank Michael Baker, Loren Brandt, Bruce Chapman, Stanley Engerman, Farley Grubb, Arthur Hosios, Naomi Lamoreaux, Frank Lewis, John Murray, Joanne Roberts, Jean-Laurent Rosenthal, Aloysius Siow, and Ken Sokoloff, all of whom provided very helpful commented on earlier drafts. The Connaught Fund and the SSHRCC (\#410-98-0426) provided financial support.
} 
Traditionally boys acquired the skills of most trades through a formal apprenticeship. They lived with their master, and over the years of their term acquired a comprehensive knowledge of their master's trade. Some time before the first manufacturing censuses in North America (in the middle of the nineteenth century), however, the proportion of boys serving apprenticeships began to fall. Ultimately, apprenticeship effectively disappeared from the US and Canadian labor markets. In contrast, it continues to thrive in Europe to this day. What are the reasons for these divergent paths? This question remains largely unanswered, in part because we have yet to establish when apprenticeship started to disappear in North America.

In this paper I examine trends in apprentice contracting in Montreal between 1791 and 1842 to pinpoint the years in which the decline began. ${ }^{1}$ This period is useful for studying the origins of this transformation because it pre-dates major technological innovations in most crafts and widespread public schooling. Apart from its intrinsic interest, Quebec offers the best, most comprehensive data on apprenticeship in North America. ${ }^{2}$ As in other Roman-based civil law jurisdictions, Quebec maintained a well-developed notarial system of signing and retaining contracts. During this half-century, Montreal's notary publics drafted and retained copies of more than 3,000 articles of apprenticeship. Signing apprentice contracts was very widespread in Montreal, even among relatives (although unusual between father and son), and in most trades and professions. ${ }^{3}$ In contrast, apprenticeship contracts in most American jurisdictions were

\footnotetext{
${ }^{1}$ Similar work has been undertaken to explain the decline in the numbers of indentured servants contracting for passage to America. See Grubb (1994a, 1994b, 1994c), Galenson (1984).

${ }^{2}$ Other studies of Quebec apprenticeship include Audet (1975), Burgess (1987, 1988), Hamilton (1995, 1996), Hardy and Ruddel (1977), Moogk (1973), Ruddel (1969), Poutanen (1985), and Sweeny (1985).

${ }^{3}$ Apart from the usual array of craftsmen, apprentices in Montreal were hired by doctors, lawyers, grocers, merchants, tavern keepers, auctioneers, post masters, surveyors, treasurers, cashiers, farmers, and managers of the local circus.
} 
registered sporadically with municipal authorities. ${ }^{4}$ While unique in some respects, the apprentice market in Montreal was similar to the New England market. Apprenticeship existed within a competitive labor market throughout North America-there were no guilds or formal certification process in any craft, and many masters operated in most trades in the larger cities. ${ }^{5}$

To account for the decline of apprenticeship, I focus on two hypotheses raised in previous studies. ${ }^{6}$ The first reasons that firms grew less interested in training labor as their production methods increasingly favored unskilled labor (and later became more capital-intensive). ${ }^{7}$ Comparing the 1820, 1832, and 1850 manufacturing censuses, for example, Goldin and Sokoloff (1982, 1984) demonstrate that firm size grew substantially over this period in many industries, and that firms with a higher proportion of unskilled labor (women and children) operated on a larger scale. The second hypothesis centers on contract enforceability. Proponents argue that long-term labor contracts of any sort became increasingly infeasible after the Revolution because American workers sought more freedom—-the right to quit. ${ }^{8}$ Long-term contracts are thought to have become less enforceable once American courts became more sympathetic to employees in

\footnotetext{
${ }^{4}$ It is possible that written indentures were generally less common in the United States. It was customary to register apprenticeships for poor or orphaned children, but this provides a distorted view of training contracts. The registers recorded only the principal terms of the contract. See, for example, Holly Brewer (1994).

${ }^{5}$ For a recent discussion of the role of the guild system in European apprenticeship, see Steven Epstein (1998). On American apprenticeships see Bridenbaugh (1950), Hansen (1997), Jacoby (1991a), Holcomb and Jacoby (1997), Murray (1999), Lachance (1994), Quimby (1985), and Rorabaugh (1986).

${ }^{6}$ There are other hypotheses in the literature. For example, Elbaum (1989) argues that the absence of guilds in North America contributed to the institution's instability. This factor is not relevant here because it cannot shed light on the timing of changes in the incidence and form of apprentice contracting that occurred in early nineteenth century Montreal.

${ }^{7}$ Craig and Field-Hendry (1993), Goldin and Sokoloff (1982, 1984), James (1983), Sokoloff (1984), Summers and Clarke (1980). See also Atack (1987, 1995).

${ }^{8}$ Steinfeld also argues that workers' republicanism may have arisen because the average worker felt they had greater opportunities for advancement and wealth accumulation in America relative to Britain. This argument holds for Canada as well as America. Contemporary expression of this view can be found in Susanna Moodie's writing. Moodie (1852: chapter 5).
} 
specific performance labor disputes. ${ }^{9}$ These models offer different predictions regarding the characteristics of the decline, which I pursue in the paper.

I find that the decline of apprentice contracting began with the War of 1812. A widespread drop in masters' propensity to sign contracts characterized the initial downturn—a grassroots rejection that spanned trades and occurred in what were likely small artisan shops. Changes in compensation and the nature of the contracts indicates that masters initially responded to a greater difficulty in enforcing the traditional long-term arrangement (a consequence, I posit, of rapid postwar population growth). The lure of high paying jobs in larger, factory-like, firms also had an adverse affect on the apprentice market, but direct signs of this effect do not appear until the late-1820s and 1830s.

\section{Data}

\section{Overview}

The data set consists of the surviving population of male, craft apprentice contracts signed by notary publics working in Montreal between 1791 and 1842 with fairly complete information (known age, contract duration, pay (if applicable) and ethnicity) — a total of 2,749 contracts. ${ }^{10}$ Records for all of the notaries operating in Montreal were examined and all apprentice contracts were coded. Most were hand-written, although forms (with blank areas) became more common over time. The language of most documents was French, although English became more prevalent in the nineteenth century, reflecting a change in the composition of Montreal's population.

\footnotetext{
${ }^{9}$ Rorabaugh (1986), Steinfeld (1991) and Wright (1995) make this argument. For more on long-term (historical) contracts and enforcement, see Grubb (1997), Ramseyer (1996), and Steinfeld and Engerman (1997). For more information on the laws governing apprenticeship in America, see Jacoby (1991b) and Steinfeld (1991).

${ }^{10}$ Natural disasters or negligence destroyed few Montreal documents over this time period. In total, 3,602 craft, male apprentice contracts were signed over the relevant period; 853 were dropped from the population of contracts
} 
Table 1 illustrates some aspects of contract structure over the sample period. It appears that the fundamental obligations between apprentices and their masters did not change appreciably over the half-century. The vast majority of contracts included a promise from the master to teach his apprentice all aspects of his trade (93 percent). ${ }^{11}$ There was a small decline over time in the use of this statement, it was especially low in the immediate postwar era (only 79 percent of contracts signed between 1817 and 1823 included it), and rebounded thereafter. For their part, boys usually began their term when they were 15 years of age and promised to serve and obey their master for about five years. Contracts rarely enumerated an apprentice's specific responsibilities, but sometimes indicated that he would not be responsible for chores unrelated to his master's craft.

Shop Size

In the empirical analysis, masters that operated in a business partnership are distinguished from those who did not, to delineate between masters that were more likely to have begun operating larger, de-skilled shops from those running traditional artisan shops. Firms with partnerships likely operated with more capital and labor than single-artisan shops. ${ }^{12}$ Multiple

\footnotetext{
because of incomplete information. In most cases (714 contracts), the apprentice's age was unknown. See the appendix for a list of craft occupations.

${ }^{11}$ A typical example is found in the records of the notary public, N.S. Hunter: "the said [master] doth hereby bind and oblige himself to teach and instruct or cause the said apprentice to be taught and instructed in all the branches of the said trade." (contract \#185, September 23, 1834). The 'teach' clause very occasionally restricted the masters' obligations to a component of the trade. Most of these restrictions appeared in the tailoring trade, where masters indicated that they were not going to teach the apprentice to cut.

${ }^{12}$ This was also the case in early nineteenth century American manufacturing. For example, Sokoloff (1982: 272-75) finds a significant positive correlation between the incidence of multiple ownership and the number of employees in the establishment in each of the 1820 and 1832 manufacturing censuses. Note that other factors, such as masters' lifecycle, could also affect partnership rates. A craftsman might seek a partner when he is young and his access to capital is weak, and when he is older and his son takes on a larger role in his business. If young and old men run small shops, the expected relationship between partnership and shop size would be negative. On average, though, the observed relationship between shop size and partnership is positive.
} 
ownerships (partnerships) were a small but growing component of Montreal apprentice contracts, covering 14.2 percent of contracts and 7.5 percent of masters in the data set (Table 1$){ }^{13}$

The number of active apprentice contracts a master held at the time a new apprentice was hired (NAYRHIRE) also proxies for shop size. This measure is computed by summing all of the contracts signed by a master and active in the year a new apprentice was hired (a five year contract signed in 1795 is considered active for years 1795 through 1799, unless it was annulled earlier). ${ }^{14}$ It has a minimum value of one (the new apprentice hired), and represents a minimum bound on a master's work force, since it captures contractual commitments only. ${ }^{15}$ NAYRHIRE rose over time, from 2.0 in the 1790 s to 2.7 in the 1830 s (Table 1), and was higher for masters in partnership (averaging 4.68, compared to 2.18 for contracts involving non-partnered masters).

\section{Compensation}

Pay is defined a few different ways. Total pay $\left(V_{R, N}\right)$ is the present discounted value of the stream of all real or nominal payments (subscript $R$ or $N$ ), including end payments, over the life of the contract, using a five percent discount rate. Average annual pay $(V / T)$ is total pay divided by the apprenticeship duration. ${ }^{16}$ Hence,

$\frac{V}{T}=\left[\sum_{t=1}^{T} \frac{c_{t}}{(1+r)^{t-1}}+\frac{V E P}{(1+r)^{T-1}}\right] / T$,

where $T$ is the duration of the apprenticeship, $c_{t}$ is the cash payment given to the apprentice in year $t, V E P$ is the cash value of the end payment, and $r$ is the discount rate. To calculate real

\footnotetext{
${ }^{13}$ The rate of partnership for a master is defined as a binomial equal to one for masters that ever listed a co-master, and zero otherwise. If it is defined instead as a master's average partnership rate across the contracts he signed, partnerships covered 6.5 percent of contracts and 5.3 percent of masters.

${ }^{14}$ Annulments usually were recorded on the original contract. On occasion, they have been traced through separate annulment documents or a subsequent contract.

${ }^{15}$ NAYRHIRE misrepresents the true number of apprentices in a shop to the extent that masters made use of nonregistered agreements.
} 
values, payments were deflated using a clothing price index. This is most appropriate because the cash payments typically were for clothing and sundry purchases, not room or board. Because no such index has been developed yet for Montreal, Quebec, or Canada over the relevant time period, T.M. Adam's (1944) series for rural Vermont was employed. ${ }^{17}$ While this series is not entirely satisfactory, it displays the accepted pattern of price deflation between 1815 and 1850 .

Apprentices' compensation varied considerably across contracts and over time (Table 2). The vast majority of boys lived with their master, receiving 'room' and 'board,' and either clothing or a cash allowance. It was quite uncommon for a boy to receive all necessities in-kind in addition to cash payments. The proportion of boys receiving cash increased markedly over time, from 35 percent in the 1790 s up to 82 percent in the 1830 s, and the proportion of boys promised clothing in-kind fell commensurately from 60 percent to 20 percent. Because all boys did not receive cash payments or room and board, deriving a comparable pay series across contracts is not straightforward. Excluding contracts without cash from an analysis of pay behavior is not advisable because it will yield biased estimates of compensation if the incidence of cash and pay are correlated. ${ }^{18}$

To help take account of possible sample selection bias, cash payments for contracts without cash are imputed from the sample of contracts with cash pay. Multivariate regressions provide estimates of the cash a boy would have received, had he been paid in cash, given his and

\footnotetext{
${ }^{16}$ The different currencies found in the contracts have been converted to a single unit of account, Halifax currency, which became increasingly common over time. The exchange rates employed are: $\$ 4$ (Spanish silver) $=£ 1$ currency $($ Halifax $)=24$ livres $($ old money; ancien cours $)=£ 0.90$ sterling (before 1820$)$.

${ }^{17}$ Adam's (1944) series reflects the price of cloth, ready-made clothing, and shoes. For other work on early nineteenth-century price indices, see Williamson and Lindert (1980), Margo and Villaflor (1987), Sokoloff and Villaflor (1992), and the series in the U.S. Bureau of the Census (1997).

${ }^{18}$ It is plausible, for example, that the 'best' boys received cash (if boys prefer cash to in-kind compensation). If so, the observed mean wage will overstate the underlying 'true' mean of the distribution of wages. The magnitude of this bias would fall over time, as cash payments became more prevalent.
} 
his master's attributes. ${ }^{19}$ Room and board plus cash pay, the most common compensation package, is used as a benchmark. The data reported and used in subsequent analyses are a hybrid of the predicted and actual cash payments - the actual values for the contracts with the relevant cash payment and the predicted values for the contracts without the cash payment. To impute cash as a supplement to room and board for all contracts requires three steps (row numbers listed below correspond to rows in Table 2, which documents the estimates).

\section{$\underline{\text { Step } 1}$}

First, in-kind end payments had to be 'converted' to cash. One-third of contracts included an end payment, and 78 percent of these payments were in-kind (row 7). An end payment is comparable to freedom dues in indentured servant contracts—it was usually a new suit of clothing received at the end of the apprenticeship. The value of in-kind end payments is estimated for contracts with end payments, using the sample of contracts with cash end pay. The estimating equation is:

$V E P=f\left(\right.$ Age, Age $^{2}$, French $_{a}$, Sign $_{a} ;$ French $_{m}$, Sign $_{m}$ Partner, NAYRHIRE $;$ Trades $;$ YEAR effects $)$

where $a=$ apprentice, $m=$ master, Trades is a series of trade dummy variables

(blacksmith/coachmaker omitted), and YEAR effects is a series of five-year-interval dummy variables (1798-1802,1803-07,..1838-42; years before 1798 are omitted). The method of estimation for each step is ordinary-least-squares. The average cash end payment was almost $£ 11$ (row 11). Conditioning on apprentice and master attributes, the estimated cash end payment for boys with in-kind end payments is $£ 8.31$ (row 12). The estimate is lower because boys who received in-kind payments were (for example) younger than boys who received cash end payments. The average hybrid value of an end payment takes on the actual values of end pay

\footnotetext{
${ }^{19}$ This method assumes that the marginal effects of explanatory variables on pay are the same for cash and in-kind recipients. It accounts for differences in observable characteristics between recipients and non-recipients, but not
} 
when it was paid in cash, predicted for in-kind end payments, and zero for contracts without end pay. It is $£ 8.89$ (Hybrid I, row 13).

\section{$\underline{\text { Step II }}$}

In the second step, a value of cash pay is estimated for the small fraction of apprentices that did not receive room or board (6.96 percent of the sample, fewer than 200 cases-row 8). First, $V / T$ is calculated for all contracts (equation 1), using the Hybrid I values for end pay. These values are shown in rows 14 and 15 . They illustrate that boys who did not live with their master (receive room or board) received much more cash per year than did individuals who lived with their master ( $£ 21.06$, compared to $£ 3.13$ respectively). ${ }^{20}$ Using these values, $V / T$ is then reestimated for contracts without room and board, using the sample of contracts with room and board (this includes contracts with and without cash). The estimating equation is the same as in Step I (equation 2), with $V / T$ as the dependent variable. On the basis of their characteristics, it is estimated that boys who did not live-in would have received $£ 5.71$ per year if they roomed with their master (row 16). It is higher than the average observed among boys who received room and board for the same reason noted above (in-kind pay was generally less common among more able boys and higher paying trades). New hybrid values of $V / T$ are then calculated, called Hybrid II, with an average value of $£ 3.34$ (row 17). Hybrid II incorporates the predicted values of $V / T$ in cases without room and board (row 16), and mostly actual V/T values otherwise (the Hybrid I values in row 14, which use the predicted values of end pay for cases with in-kind end payments).

\footnotetext{
unobservable differences. This method is employed in Baker and Benjamin (1997).

${ }^{20}$ These amounts include the predicted cash end pay amount, where applicable. Note that the nominal dollar difference is a bit misleading since most of the observations without room or board occur late in the sample period. In real dollars, boys without room or board received $£ 16.65$ annually, while the rest were paid $£ 2.35$ per year.
} 


\section{Step III}

Third, and most importantly, boys who received only in-kind compensation during the term had to be assigned a cash supplement to room and board (essentially this covers boys who received clothing instead of a clothing allowance). Forty-two percent of all contracts contained no cash during the term (exclusive of an end payment, row 9). Using the Hybrid II values of $V / T$, the value of cash pay during the term is estimated for contracts without cash (during the term), using the sample of contracts with cash. The same estimating equation is used (equation 2), with $V / T$ as the dependent variable. A final set of hybrid values are calculated (called (final) Hybrid), incorporating the predicted value of cash payments in cases without cash, and the Hybrid II values otherwise. As Table 2 illustrates, the average payment was $£ 5.14$ per year for contracts with cash during the term (row 18), and predicted to have been $£ 4.41$ for contracts without cash (row 20), yielding a Hybrid average of $£ 4.84$ per year (row 21). ${ }^{21}$ Hence this metric contains predicted values for cases with in-kind end pay or no room and board (incorporating all three steps), and actual values otherwise. It is used in subsequent analysis.

To demonstrate the temporal characteristics of these estimates, Figure 1 shows an actual and hybrid series of average annual pay $(V / T)$ over time, each in real and nominal dollars. The actual series includes only contracts with cash, room or board, and either no end pay or cash end pay-hence it contains actual pay values only. The hybrid series includes all contracts and thus takes on the estimated values of $V / T$ where applicable, and actual cash payments otherwise. This hybrid series represents the pay supplement to room or board actually or estimated to have been paid to all apprentices. As is evident in Table 2, the (actual) pay series for apprentices with cash and room or board tends to lie slightly above the hybrid series for all apprentices, because boys

\footnotetext{
${ }^{21}$ The average Hybrid II V/T value for contracts with room and board, but without cash during the term (row 19), is $£ 0.83$. It is not zero because this estimate of $V / T$ includes actual or estimated end pay values.
} 
with attributes that merited higher compensation tended to receive cash. This reverses towards the end of the period because those same boys were among the minority that no longer roomed with their master. In general, the gap between the hybrid and 'actual' pay series is small and fades over time, because pay estimates are required for a smaller proportion of the population. ${ }^{22}$

\section{When did the Decline Commence?}

\section{(i) Documenting changes in the stock of apprentice contracts}

In order to measure changes in the use of apprentice contracts over time, I define the stock (or sum) of apprentice contracts that are active in a given year. ${ }^{23}$ Hence it measures total apprenticeship employment (under contract) at a point in time. Figure 2 illustrates three-year (centered) moving averages of the contract stock between 1797 and 1842 for all contracts and the subset of contracts with partnered-masters $(P) .{ }^{24}$ Distinguishing between $P$ and unpartneredmaster $(N P)$ contracts provides a sense of the difference in the contracting behavior of large-shop versus small masters. For the full sample, the stock of contracts rose until 1814, and trended down thereafter. In contrast, the stock of $P$ contracts did not experience a downturn until the mid$1820 \mathrm{~s}$, when it faltered badly, recovered in the early $1830 \mathrm{~s}$, and fell again after $1835 .^{25}$

\footnotetext{
${ }^{22}$ Overall, pay had to be estimated in 69 percent of contracts signed in the 1790s, and 33 percent of contracts signed in the 1830s (Table 2, row 10).

${ }^{23}$ Recall that a contract is considered active for the years of its stipulated duration, unless it was annulled earlier.

${ }^{24}$ The stock calculations for 1791 to 1796 are omitted because of truncation bias that arises because contracts signed in the 1780s, and still in progress in the early 1790s, are not in the data set.

${ }^{25}$ Decomposing the overall stock growth rate into its partnered and unpartnered components reveals that both types of contract contributed to the decline in contracting, with the role of $P$ contracts especially important in the latter part of the 1830s. Given that the overall growth rate is a weighted average of the partnered and non-partnered growth rates $\left(\dot{N}_{t}=s_{t}^{p} \dot{N}_{t}^{p}+\left(1-s_{t}^{p}\right) \dot{N}_{t}^{n p}\right)$, where $s_{t}^{p}$ is the share of partnered-master contracts, the impact of each factor on growth can be computed by calculating counterfactual growth rates hold either $\dot{N}_{t}^{p}$ or $\dot{N}_{t}^{n p}$ or $s_{t}^{p}$ constant at its average level during the first decade, 1798-1807. The average growth rate was 9.11 percent between 17981802 , and -3.1 percent between 1838-42. Holding the share constant at its average value in the first decade (17981807), the growth rate would have changed from 10.05 percent in the first 5 years $(1798-1802)$ to -2.1 percent in the last five years. Hence the share change explains 8.2 percent of the change in the growth rate $(-3.1+2.1) /(-3.1-9.11)$. Over the same time periods, changes in the growth rate of $P$ contracts explain 47 percent of the drop in the overall growth rate, while changes in the $N P$ contract growth rate explain 39 percent of the actual change. The results of
} 
Changes in the stock of apprentice contracts understate the decline in the rate of contracting within the labor force because it does not take account of growth in the stock of boys available in the city. While it is not possible to obtain a reasonable count of the population of boys in the city over time, it is possible to examine the ratio of the apprentice stock to the city's population. ${ }^{26}$ When population growth is taken into account, the decline is much more pronounced and also turns around the time of the War of 1812 when the city experienced more immigration and hence faster population growth (Figure 2). These data clearly establish the Napoleonic war as a watershed-this is the point when apprentice contracting, both in relative and absolute terms, began to falter. Furthermore, the data reveal that the postwar decline was largely a small-shop $(N P)$ experience.

\section{(ii) Components of the Apprentice Stock}

In order to uncover the characteristics of the decline, it is useful to think of the stock of apprentices at a point in time $\left(N_{t}\right)$ as a function of the proportion of the master population hiring apprentices under contract in year $t$ and the number of active contracts held per master in that year:

$$
N_{t}=\alpha_{t} M_{t} \times \frac{N_{t}}{\alpha_{t} M_{t}}
$$

where $\alpha_{t}$ is the contracting rate and $M_{t}$ is the master population in year $t$. Hence the stock of contracts can fall because of a drop in the population of masters $\left(M_{t}\right)$, the contracting rate $\left(\alpha_{t}\right)$,

this sort of exercise are sensitive to the time periods examined, but give a rough sense of the relative magnitudes. See Lewis (1981) for another application of this technique.

${ }^{26}$ Detailed censuses of Montreal that breakdown the population by gender and age were undertaken in 1825 and 1844, but not before. Between 1825 and 1844 Montreal's population grew from 22,540 to just over 44,000. The number of males aged 14 to 18 rose from 977 to 1,832 , or from 4.33 percent to 4.55 percent of the population. The share of teenager males as a fraction of the male population increased from 8.61 percent in 1825 to 9.51 percent in 1842. These data indicate that at least between 1825 and 1842 total population is a reasonable numeraire. If anything, it may understate the growth in the population of teenage males and thus the decline in the proportion of apprentices to young males in the population. Census of Canada, Vol.4, 1871. 
or the number of active contracts held per (hiring) master $\left(\frac{N_{t}}{m_{t}}\right)$, where $m_{t}$ is the number of masters hiring apprentices under contract $\left(m_{t}=\alpha_{t} M_{t}\right)$. A change in the overall contracting rate might occur because of changes in occupation mix (towards trades that were less likely to contract with apprentices) or a general decline in the use of apprentice contracts.

To distinguish between these possibilities requires a measure of the craftsmen population in Montreal. While there was no census of manufacturing during this period, two city directories (one in 1819 and one in 1843) provide measures of the craft population. ${ }^{27}$ The directories list an individual's name, occupation, and residence. They do not distinguish between masters and workers in a trade (journeymen, for example), but are nonetheless a useful metric of adults working in trades. ${ }^{28}$

Table 3 reports the number of people listed in each directory, by trade, and the proportion of them that appear as masters in the population of apprentice contracts. ${ }^{29}$ First, it shows that the number of people in the directories, listed in the twelve trades examined, rose three-fold between 1819 and 1843 . This increase more than kept pace with population growth: the directory listings constitute 3 percent of Montreal's population in 1819 and 4 percent in 1843 . Hence it is quite unlikely that a drop in the master population $\left(M_{t}\right)$ caused the decline in the contract stock.

Second, Table 3 reveals a decline in the usage of contracts among those listed in the directories - 27 percent of individuals listed in the 1819 directory signed contracts before 1819 and 16 percent of those listed in the 1843 directory signed contracts before 1843 (a 42.6 percent drop). The city directories can also indicate whether contracting usage varied across partnered and unpartnered masters because some of the directory entries are of 'partnerships' (such as Shay

\footnotetext{
27 Doige (1819) and MacKay (1844).

${ }^{28}$ The occupational distribution in the apprentice contract data set is similar to that found in the city directories: blacksmithing, carpentry, and shoemaking are the largest trades in both samples. Compare Tables 1 and 3.
} 
and Bent; William and Thomas Molson; George Bourne and Co.). While it is doubtful that all partnerships were recorded in each directory, there is little reason to suspect that such selection is correlated with contract usage. ${ }^{30}$ Consistent with them operating larger shops, people listed in partnerships exhibited a much higher contracting rate than observed among the directory population (67 percent in 1819, compared to 27 percent overall). Their contracting rate, however, was also markedly lower in $1843,37.5$ percent (Table 3$)$. The percentage decline (43.8 percent) is a bit larger than that experienced by the non-partnered directory population (40.4 percent). A trade-by-trade analysis of contracting use indicates that there was variation in the rate of decline, but there is no correlation between (directory) population growth and contracting rates across trades. Hence the overall decline in the contracting rate is not due to a structural shift towards trades with low contracting rates. The decline was widespread, with all except the leather trades experienced declines. ${ }^{31}$ This evidence points to a widespread decline in the contracting rate $\left(\alpha_{t}\right)$ between 1820 and 1840 — one experienced by most trades and both partnered and unpartnered masters. $^{32}$

\footnotetext{
${ }^{29}$ This was accomplished by directly linking, on a trade by trade basis, the names in the directory with the names of masters signing contracts.

${ }^{30}$ In general, it seems likely that undercounting of partnerships was worse in the 1843 directory, when they actually comprised a lower proportion of entries. Partnerships comprised 4.9 percent of entries in 1819, compared to 2.7 percent of the entries in the 1843 directory. In contrast, 9.5 percent of masters with contracts that were active between 1816 and 1818 were in partnerships, as were 11.4 percent of masters with contracts active between 1840 and 1842.

${ }^{31}$ The largest reductions occurred among both small-scale trades (butchers fell by 65 percent), as well as trades that tended to operate on a larger scale (furniture/carpenters dropped by 63 percent, and hatters by 56 percent).

${ }^{32}$ The decline in the proportion of people in the directories signing contracts may not, however, reflect a true rejection of apprentice contracts if, for example, the 1819 proportion (27 percent) is overstated. At first glance there is reason to suspect this, since the coverage in the 1819 directory appears to have been worse than the 1843 directory (about 50 percent of masters signing contracts between 1816 and 1818 are listed in the 1819 directory, compared with 70 percent coverage in the 1843 directory for those signing contracts between 1840 and 1842). Greater undercounting of the population of 1819 masters means that the proportion of people listed in the 1819 directory signing contracts ( 27 percent) would be understated if the people missing from the 1819 directory tended disproportionately to sign contracts, or biased upward if they tended not to sign contracts. It appears, however, that the missing masters tended to sign contracts: across trades, there is a positive correlation between coverage and the proportion of the directory enumerated signing contracts in the 1819 case; and no relationship between the two variables in the 1843 case. This suggests that if the coverage rate had been higher in 1819, the signing rates also would have been higher.
} 
The third factor, the number of active contracts per (hiring) master $\left(\frac{N_{t}}{m_{t}}\right)$, also appears to have contributed to the decline in the apprentice stock in the postwar era. Figure 3 illustrates the actual apprentice stock and two counterfactual stocks that respectively hold the stock of masters $\left(m_{t}\right)$ and number of apprentices per master $\left(\frac{N_{t}}{m_{t}}\right)$ constant at their average values between 17981807 (recall that $N_{t}=m_{t} \times \frac{N_{t}}{m_{t}}$ ). It illustrates that variation in the stock of masters with contracts $\left(m_{t}\right)$ was largely responsible for variation in the apprentice stock—particularly stock growth prior to 1815 . It also indicates, however, that if the stock of masters had remained constant the apprentice stock would have fallen in the immediate postwar era because of variation in $\frac{N_{t}}{m_{t}}$ $\left(C F(\underline{M})\right.$ in Figure 3). ${ }^{33}$ In contrast, had $\frac{N_{t}}{m_{t}}$ remained constant at its $1798-1807$ average the apprentice stock growth rate would have stagnated in the postwar era, but the absolute decline would not have begun until the late-1820s $(C F(\underline{N / m})$ in Figure 3). Thereafter the decline in the contracting rate is reflected in an absolute decline in the master stock $\left(m_{t}\right)$. Hence variation in number of active contracts per (hiring) master also contributed to the postwar decline in the apprentice stock.

\section{(iii) Stocks and Flows}

Additional insight into the rejection of apprentice contracting can be gained by considering the flows into and out of apprenticeship. Defining $E_{t}$ as the number of new apprentice contracts signed in year $t$ (entrances), and $X_{t}$ as the number of apprentices exiting in year $t$ (completing or annulling their contract), the stock of apprentices can be defined as:

The observed decline also may overstate the true decline if the proportion of 'masters' within the population of tradesmen declines over time. This may have been the case, since shop sizes were growing over this period. This measurement issue will not arise for individuals listed in partnerships, though. As is discussed below, they experienced similar rates of decline in the proportion signing contracts. 


$$
N_{t}=N_{t-1}+E_{t}-X_{t}{ }^{34}
$$

Hence the growth rate in the apprentice stock is the difference between the entrance and exit rates:

$$
\dot{N}_{t}=\left(N_{t}-N_{t-1}\right) / N_{t-1}=E_{t} / N_{t-1}-X_{t} / N_{t-1} \text {. }
$$

To illustrate, Table 4 lists the stock of contracts, the number of entrances and exits (as well as the stock of active masters) for select years between 1798 and 1842. Over time, the exit rate rose while the entrance rate fell slightly_directions consistent with a decline in the growth rate. ${ }^{35}$ To illustrate the relative impact of changes in entrance and exit rates on the stock's growth rate, Figure 4 illustrates two counterfactual growth rates, one that holds the exit rate constant, the other that holds the entrance rate constant, at their average value in the first decade (1798-1807). It indicates that the rise in the exit rate contributed more to the overall (40-year) decline in the contract stock growth rate than the slight negative trend in the entrance rate. ${ }^{36}$

Why did the exit rate rise over time? In any period, the exit rate depends on the time served (tenure) by previously hired apprentices, which depends on the apprenticeship duration stipulated in the contract, and annulment behavior. ${ }^{37}$ Figure 5 illustrates that new apprentices'

\footnotetext{
${ }^{33}$ Even partnered-masters reduced the number of contracts per master following the war, but their apprentice stock continued to grow because the master stock was still rising.

${ }^{34}$ Note that this method does not allow us to distinguish between the components of the apprentice stock addressed in the previous section, because variation in the flows (such as the entrance rate) can be caused either by changes in the number of contracts held per master $\left(\frac{N_{t}}{m_{t}}\right)$ or the number of masters signing contracts $\left(m_{t}=\alpha_{t} M_{t}\right)$.

${ }^{35}$ Simple OLS regressions of the trend in the exit and entrance rates indicate a statistically significant upward trend in the exit rate, but an insignificant trend in the entrance rate (the coefficient on YEAR, defined for years 1797 to 1841, is 0.0017 for the exit rate, and -0.0004 for the entrance rate). The subset of partnered-master contracts exhibits similar exit behavior, but the entrance rate fell significantly.

${ }^{36}$ A rudimentary way to determine the relative contribution of each factor to the overall growth rate is to regress each hypothetical growth rate on the actual growth rate $\left(\dot{N}=\alpha+\beta_{i} \dot{N}_{C F i}\right)$, where $C F i$ is the $i^{\text {th }}$ counterfactual $(C F)$. The coefficient, $\beta_{i}$, represents the 'factor share' (and $\sum_{i} \beta_{i}=1$ ). Adopting this methodology, the exit rate's share in growth is 0.63 , while the entrance rate share is 0.37 .

${ }^{37}$ Tenure is defined as the length of the apprenticeship for contracts that were not annulled, and the length of time completed for annulled contracts.
} 
average tenure began falling fairly steadily in the postwar era. ${ }^{38}$ It also reveals that this decline was due to changes in the average duration of apprenticeships, and not changes in annulment behavior. In fact, the annulment rate actually declined fairly steadily over the entire 40-year period, which would have put upward pressure on tenure over time as a higher proportion of contracts were completed. ${ }^{39}$

Many factors contribute to the stipulated duration of an apprentice's contract, but the most important factor is a boy's age. ${ }^{40}$ In fact, age alone accounts for more than half of the variation in duration. ${ }^{41}$ Accordingly, Figure 5 shows that the drop in term length was matched roughly by a rise in apprentices' age at the time they began their contracts.

\section{(iv) Summary}

Apprenticeships in Montreal began to decline after the War of 1812, both in relative (per capita) and absolute terms. The contraction is first seen among small artisans (unpartneredmasters), although the decline was ultimately greater in partnered shops. It was driven by a significant drop in the contracting rate among the population of masters, at least between 1820 and 1840. Also, there was a fall in the number of apprentice contracts held per (hiring) master. Finally, the postwar downturn did not affect all boys uniformly-it was characterized by a move away from long contracts involving younger boys. Any account of the decline of apprenticeship in this era should encompass these elements.

\footnotetext{
${ }^{38}$ New contracts are those contracts signed in the corresponding year.

${ }^{39}$ The annulment rate decline was quite steady except during the war (1807-12), when it was well below trend.

40 This issue is addressed in Hamilton (1996).

${ }^{41}$ Without any other controls, the linear trend in duration is estimated to be -0.028 per year (or -1.4 years over 50 years). Adding age (a single variable equal to the apprentice's age at the start of the contract), the trend in duration falls to -0.0085 per year (or - 0.425 over 50 years). A significant (but small) negative trend in duration exists even if other apprentice and master attributes are included. Variation in starting age alone accounts for 68 percent of the variation in apprentice duration.
} 


\section{Explaining the Postwar Decline: Two Hypotheses}

\section{(1) Enforceability}

Two hypotheses, commonly raised in the literature, guide the analysis. One is that it became more difficult to enforce a traditional long-term apprenticeship contract after the war. Enforceability was an important issue in the traditional apprenticeship because the master typically invested first, and recouped his investment later in the term. To explain, consider a boy's productivity and pay paths. The boy usually lived with his master, received room, board, clothing or a clothing allowance, and often an extra payment at the end of his term. While it is impossible to say whether the value of in-kind compensation changed over the course of the apprenticeship, explicit accommodation for increases in the value of the apprentice's compensation over his term were virtually unheard of (apart from the end payment). Even if he received a cash allowance, the amount specified typically remained (nominally) constant throughout the apprenticeship. Contrast this with the expectation that the boy would become more productive as his term progressed. In a competitive environment, boys were almost certainly receiving more than they were worth early in the term, and less than they worth towards the end. In other words, masters invested in their charges early on, and recouped their investment as the boy learned and became more productive.

To mitigate the risk associated with the delay until the master's investment paid off, contracts tended to incorporate various enforcement mechanisms. These included end payments, explicit parental liability, and legal recourse. These mechanisms limited the cost masters incurred with a contract breach and helped to ensure that boys would not find quitting attractive. ${ }^{42}$

\footnotetext{
42 Issues of contract enforcement and breach in Montreal apprenticeships are discussed in some detail in Hamilton (1995).
} 
Enforcement mechanisms did not necessarily mitigate the costs of breach at each point of time during the contract, but, given a sufficient degree of trust and an informed match, both sides could be reasonably certain that the terms would be fulfilled. End payments, for example, made 'running away' less attractive to apprentices approaching the end of their term because they would forfeit this bonus. If the master set the end payment 'too low,' though, the boy might have absconded anyway, causing the master to lose part of the return on his investment.

In general, the quality of information each side had about the other before contracting was key to the viability of these long-term arrangements, because the decisions regarding term length and appropriate enforcement mechanisms depended on a reasonably accurate assessment of a boy's future productivity, for example. Masters (and apprentices' families) attempted to reduce the uncertainty associated with a match through the use of probationary periods or by hiring the children of families that were better known to them (neighbors). ${ }^{43}$

Information also would have enabled masters to make a more accurate evaluation of the expected effectiveness of different enforcement mechanisms, such as parental enforcement. Traditionally it took the form of parents agreeing to track down and return their wayward sons. By signing the agreement as the child's legal tutor, they also became legally culpable for their charge's contractual obligations. The former provision involved an element of trust between the master and the parents - the master had to know the parents well enough to believe that they would actively search for their son and see to it that he fulfilled his obligations. At the extreme, the latter aspect involved legal recourse. If the boy did not honor the contract, parents with a reputation to uphold in town and well known to the master may have readily compensated him for his loss. With a less intimate relationship, there may have been a greater chance of court involvement (a costlier venue). 
Several factors could have reduced the effectiveness of traditional enforceability after the war. First, the postwar flood of new immigrants (primarily from Britain) may have adversely affected the quality of information both masters' and potential apprentice families' had about one another before hiring. With less information, the risks associated with traditional contracts—both in terms of assessing future productivity and the expected loss from a premature breach-may have made such contracts untenable. It is also possible that the war diminished workers' taste for long-term commitments. Substantive changes to the master-servant laws also could have affected enforceability adversely, but no such change took place over this period. ${ }^{44}$

If traditional arrangements became less enforceable masters are expected to have preferred contracts that involved less risk. A number of predictions follow. First, one way to dissipate risk would have been to avoid hiring young boys. Young (less productive) boys served longer terms, hence the investment period was longer, and the return on the investment not realized until further into the future. ${ }^{45}$ As a result, longer-term (riskier) contracts tended to include more enforcement mechanisms (see Hamilton, 1995). The risks associated with young boys were also higher because of the added difficulty of accurately guessing his future

\footnotetext{
${ }^{43}$ See Hamilton (1996).

${ }^{44}$ The master and servant laws in Lower Canada did not change substantially during the first half of the nineteenth century; hence a shift in court behavior is at least not readily apparent. Of course a change in the court's treatment of servants and masters can be documented only through examination of court cases in conjunction with the laws. Such a study is beyond the scope of this paper. Documents consulted include Provincial Statute of Lower Canada: Geo III, 1802, chap. 11; Geo III, 1803, chap. 4; Geo III, 1807, chap. 4; Geo III, 1811, chap. 13; Geo III, 1817, chap. 16; 4

Geo IV, 1824, chap. 33; 9 Geo IV, 1829, chap. 37; 16 Geo IV, 1836 chap. 27. See also "Rules and Regulations of the Police for the City and Suburbs of Montreal," District of Montreal, Court of Quarter Sessions: 1810 (published in the Montreal Gazette, Sept 17, 1810); 1817 (April 30, chapter 7); January, 1821; and "Additional Regulations respecting Apprentices and Hired Servants" (ratified by Court of King's Bench, June Term, 1811), published in the Montreal Gazette, July 151811.

${ }^{45}$ This argument assumes pay was competitively determined. Supposing that young boys were initially less productive than older boys (at the start of their term), then short contracts with young boys were not likely profitable unless annual compensation could be reduced accordingly. Basic necessities may have constituted a minimum bound. Even if it did not, young boys could not achieve a sufficiently skilled level of productivity unless they served longer or learned more quickly than older boys. The latter seems unlikely.
} 
productivity and aptitude for a trade. ${ }^{46}$ Consequently, masters are expected to have reduced their demand for young boys, turning to shorter, less risky contracts, involving older boys (Figure 6a). Second, if the postwar surge in immigration diminished the familiarity of master-apprentice matches one would expect a higher proportion of contracts (involving boys of all ages) to rely less on enforcement mechanisms that involved as much mutual trust and prior information.

\section{(2) The Goldin-Sokoloff Thesis: The Rise of Big Firms}

The second hypothesis centers on the rise of large shops. The demand for domestically produced goods was likely buoyed by wartime trade shocks and rapid postwar population growth. Financial intermediation progressed around this time (Montreal, and Canada's, first bank opened in 1817) and transport routes improved (for example, construction on the Lachine canal began in 1819 and finished in 1824). Increased local demand and companies' market reach may have spurred firms to produce on a larger scale with production methods that incorporated greater division of labor. As Goldin and Sokoloff demonstrate, this generally entailed greater use of women and children (unskilled labor) and less skilled (adult male) labor, which caused children's relative wage to rise. In other words, the demand for child labor rose in firms making this transformation, causing children's wage to rise.

These firms are expected to have had less interest in training workers (because they relied less on skilled labor), hence their demand for apprentice labor is expected to have fallen. An immediate reduction in their demand for apprentices seems unlikely, though, given the growth in their overall demand for children and the entrenchment of contractual apprenticeships in the child labor market. If there was some inertia, the share of $P$ contracts in the apprentice stock, as well as observed 'shop size' (NAYRHIRE), may have grown in the postwar era. At the same time,

\footnotetext{
${ }^{46}$ Probations, however, were not employed as often with very young boys, likely because it was difficult to garner information concerning craft aptitude and match quality in a reasonable time frame.
} 
higher wages in large shops are expected to have drawn apprentices out of traditional artisan shops (and larger shops if the demand for apprentices in these firms did not keep pace with their demand for casual child labor). Apprentice supply is expected to have fallen until wage equilibrium was re-established (at a higher wage). ${ }^{47}$ Note that this predicted negative supply shock would be consistent with the observed rise in apprentices' starting age if younger boys had more incentive to defect to the factory-like job market. This would have been the case if wages were less age dependent in unskilled jobs in large shops (this scenario is depicted in Figure 6b).

Changes in enforceability are not otherwise anticipated, except to the extent that masters in large firms were less familiar with their many charges than a small artisan. Large shops are expected to have had a preference for older boys, with shorter contracts, and enforcement mechanisms that better mitigated the damages from breach, because masters hiring many boys likely did not know each as well as masters hiring just one or two boys. In this sense the predictions of these two hypotheses are indistinguishable, except that small shops are not expected to follow suit unless such arrangements were superior or boys preferred them.

Hence, the catalyst in both hypotheses is rapid population growth, but each emphasizes different, but not incompatible, consequences of growth—improved local market opportunities or a decline in neighborly familiarity. It is very likely that both repercussions resonated in postwar Montreal, but some effects may have had more immediate impact on apprenticeship than others.

\section{Evidence}

In an attempt to isolate which hypothesis better explains the downturn in apprenticeship contracting, I focus on three opposing predictions of the two models.

\footnotetext{
${ }^{47}$ Note that a rise in other attractive alternatives, such as schooling, also could have led to a reduction in the supply of apprentices.
} 


\section{(1) The Rise in Big Shops}

Assuming there was some inertia in the child labor market, faster postwar growth in large shops (relative to artisan shops) is a weak, but unique, prediction of the Goldin-Sokoloff thesis. Apprentice data may not necessarily pin down the timing of the growth in factory-like employment opportunities in Montreal, because they are expected to constitute an increasingly select sample of large-shop hiring practices. Nonetheless, these data indicate that hiring practices in large shops experienced the most change in the late-1820s and 1830 s. $^{48}$ The number of new $P$ contracts was historically high in the late-1820s and early-1830s, before falling. ${ }^{49}$ The proportion of partnered-masters rose rather sharply in contracts signed immediately following the war, but this was simply because the number of $N P$ contracts fell. Among $P$ contracts, the average number of apprentices held per master (NAYRHIRE) began rising in the late-1820s and was very high in the early-1830s (see the table in footnote 49). In addition, the proportion of these contracts that did not offer room or board rose most dramatically in the 1830s (masters with large shops would have found it difficult to accommodate workers in their homes). Thus there appears to be little evidence of a marked change in the size or importance of bigger shops immediately following the war when the stock of apprentices stagnated and the per capita stock started plummeting — these effects do not appear in the apprentice data until the late-1820s or 1830 s.

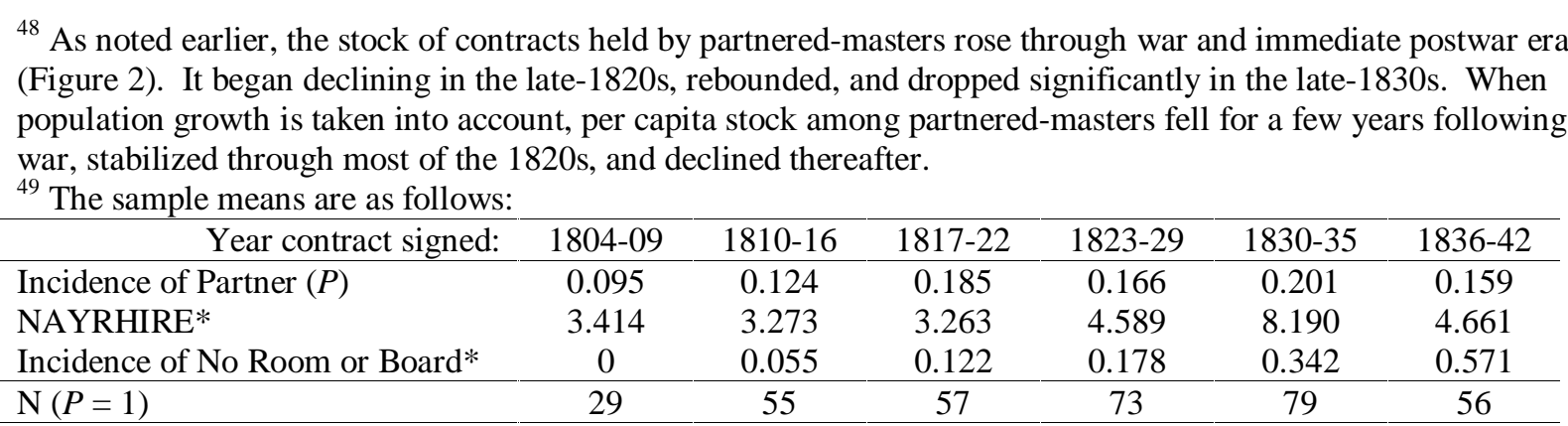

* Contracts involving (ever) partnered-masters. 


\section{(2) Demand versus Supply}

The two theses also offer different predictions concerning the market for young versus older apprentices. The enforceability thesis predicts a negative demand shift for cases involving excessive risk such as long contracts with young boys, while the Goldin-Sokoloff thesis predicts a negative supply shift (principally in small shops) which also may have been stronger among younger boys (recall Figure 6). If supply forces dominated, pay should have risen, and risen most for young boys; if demand effects dominated, pay should have declined, with young boys experiencing the largest drop.

One way to test this hypothesis is to examine total pay because it most closely represents the value or price of the contract (in a competitive market). ${ }^{50}$ In order to distinguish the intertemporal pay trends of older and younger boys, total real pay $\left(V_{R}\right)$ was regressed on apprentice and master attributes, as well as a series of individual year effects (marking the year the contract was signed), and a series of interactions between an age dummy variable (equal to one for boys beginning their term when they were 15 years old or younger), and the individual year effects. ${ }^{51}$ Controlling for master and apprentice attributes allows us to separate out the premium associated specifically with age, and not with observable variables correlated with age.

Figure 7 illustrates the time effects derived from the multivariate regression analysis. It indicates that total pay for younger and older boys moved in tandem until the end of the war. ${ }^{52}$ At that point, the start of the decline in apprenticeship, the total pay of young boys began losing ground to their older counterparts. All else equal, pay for older boys declined moderately, while pay for young boys dropped much more quickly. This pattern is consistent with a drop in

\footnotetext{
${ }^{50}$ This is similar to the argument made in the indentured servant literature. See, for example, Galenson (1977, 1981a, 1981b) and Grubb (1985,1988).

${ }^{51}$ See the notes to Figure 7.

${ }^{52}$ Complete regression results are available on request.
} 
demand for apprentices, and a relative decline in the demand for younger boys. This finding is consistent with the enforceability thesis.

Another test is provided by examining the components of total pay: duration and average annual pay $\left(V_{R}=\frac{V_{R}}{T} \times T\right)$. Figure 8 illustrates similarly determined year regression coefficients for these variables. It reveals a relative decline in the duration of younger boys' contracts, which began around 1819. In contrast, there were no changes in the trends in their average annual pay around the postwar period. Hence the decline in young boys' total real pay was caused by a reduction in the length of their apprenticeships, all else equal (which is also consistent with the enforceability thesis).

In contrast, though, the pay and employment behavior of the 1830 s fits the profile of the hypothesized Goldin-Sokoloff production shock. Figures 7 and 8 reveal a sharp break in the trends in total pay in the middle of the 1830s, when older boys' total pay rose sharply (pay for young boys continued its descent). This was caused primarily by an abrupt rise in their average pay per year. Recall that the stock of apprentices was falling rather rapidly at this time. Among young boys, the decline in apprentice stock (and further shift away from young boys) coupled with declining pay, suggests that negative demand shocks were still occurring. Among older boys, though, the stock decline and rising pay implies that the supply of older boys in the apprentice market had begun to fall. Hence older boys may have begun abandoning the apprentice market in the mid-1830s in response to greater access to attractive alternate employment. $^{53}$

\footnotetext{
${ }^{53}$ Alternatively, they may have found secondary schooling more attractive, but there is little evidence to support this claim. Secondary education appears to have been reserved for the elite throughout this period. Two high schools operated in Montreal at this time, a French school run by the Catholic Church (established in 1773) and a private English school (begun in 1810). Both appear to have been fairly small institutions with non-trivial fees. Public
} 


\section{(3) Enforceability}

Thirdly, changes in enforceability (towards less risky contracts) are directly associated with the enforceability thesis but also consistent with Goldin-Sokoloff. For the latter thesis, though, these changes are expected to have been concentrated in large shops and coincide with the growth in shop size (which appears to have occurred in the late-1820s or 1830s).

The nature of compensation changed markedly over this period (see Tables 2 and 5). As described above, most apprentices in the 1790s received constant pay during the term, with an extra lump payment upon completion. By the 1830s, end payments were relatively uncommon (just 11 percent of contracts included them, compared to 60 percent in the 1790s-Table 2).

Instead, contracts were much more likely to specify cash payments that rose during the term. Fifty-three percent of all contracts signed in the 1830s specified non-constant pay during the term (exclusive of an end payment), up from 7 percent in the 1790s (Table 5). ${ }^{54}$ These changes were virtually offsetting, as the proportion of contracts with entirely constant compensation fell only marginally (constant pay during term and no end payment).

To flesh out the timing of these changes, Figure 9 illustrates trends in average annual pay and pay in the first year of the contract, for contracts with cash, room, and board. ${ }^{55}$ It depicts both the raw means and regression coefficients from individual year dummy variables (1791-5 are the

secondary education was a phenomenon of the 1850s. See Dickinson and Young (1993: 93), Audet, Volume II (1951: 341), Hanaway and Cruess (1996: 196), and Magnuson (1980: 35).

Another gauge of potential secondary attendance is the popularity of its prerequisite, primary education. Spotty attendance reports for the principal Montreal primary school (École Nationale) indicates that attendance progressed from 38 pupils in January 1820, to 135 in May 1823, 296 in April 1824, 221 in December 1830, and 266 in January 1834 [Audet, Vol. IV (1951, pages 218, 245, 245, 161-3, 169-71 consecutively)]. Some of the variation in attendance likely reflects seasonal demand, but these figures suggest fairly rapid growth in attendance during the early 1820s. Growth in the number of primary schools in Quebec more generally also indicates rapid growth in the 1820 s and early 1830s. A comprehensive public education system was not established until the early $1840 \mathrm{~s}$ (Magnuson (1980: 23)).

${ }^{54}$ The decline was of similar magnitude among contracts with cash compensation (36 percent of contracts signed in the 1830s specified constant payments, compared with 81 percent in the 1790s, see Table 5).

${ }^{55}$ Figure 9 draws on actual pay values only because pay each year cannot be estimated accurately. 
omitted years). Both series display similar patterns—a divergence between the average and first year pay that first opens up in 1812 . Between 1812 and 1816, real average annual pay rose fairly dramatically, and instead of offering the usual compensation scheme, masters offered boys with cash compensation less pay initially and higher pay as their apprenticeship progressed. ${ }^{56}$

If the growth rate in expected productivity over the course of an apprenticeship did not change substantially over this period this change indicates that masters were reducing their initial investment in apprentices. ${ }^{57}$ Over time, masters appear to have invested less and less in their apprentices, since first-year pay was actually falling, while average annual pay remained relatively unchanged between 1826 and 1832 (the gap between average and first year pay narrowed between 1832 and 1834, but re-opened thereafter). The pay gap also implies that masters were pledging greater pay growth during a contract because they were offering lower initial pay relative to the average pay over the contract.

This change in the dynamic between expected productivity and pay constitutes a fundamental shift in the apprentice-master relationship. Masters no longer risked as much on their apprentices because boys' pay stream likely corresponded more closely to their expected productivity path. If the boy wished to leave before the end of the term, the costs associated with early dismissal were now relatively small. The arrangement was also less risky for apprentices,

\begin{tabular}{lcccc}
\hline $\begin{array}{l}56 \\
\text { For example, among five-year apprenticeships }(5 \leq \text { Duration }<6)\end{array}$ & with cash, room, and board, the average real \\
cash payment per year progressed as follows (in Halifax currency): & & \\
\hline Year & $1791-1803$ & $1804-1816$ & $1817-1829$ & $1830-1842$ \\
\hline First & 2.45 & 3.38 & 3.27 & 2.87 \\
Second & 2.61 & 3.50 & 3.60 & 3.50 \\
Third & 2.56 & 3.62 & 3.87 & 4.13 \\
Fourth & 2.61 & 3.71 & 4.25 & 4.70 \\
Fifth & 3.04 & 4.11 & 4.53 & 5.43 \\
\hline $\mathrm{N}$ & 35 & 55 & 90 & 137 \\
\hline
\end{tabular}

\footnotetext{
${ }^{57}$ In other words, the gap between expected productivity and pay during the first year or two of the contract likely was smaller with rising pay than it was under the traditional constant cash pay schedule. The only way such a shift in pay could not be associated with less initial investment on the part of the master is if postwar apprentices'
} 
because there was a greater implicit assurance that they would receive training (since masters would not breakeven if their apprentices did not become more productive as the term progressed).

Compensation was not the only change in the nature of enforcement that occurred during the early nineteenth century. Table 5 illustrates some changes in the nature of sponsors. All contracts involving minors required the presence of an adult 'sponsor' because a child's word alone was not legally binding. Usually this involved a family member (typically a parent), but a court-appointed tutor was used when no relatives were available in or around Montreal. ${ }^{58}$ Rising use of non-parental sponsors might signal a reduced level of intimacy between apprentice and master families, but it is not a definitive measure because the proportion of parent-sponsors could have remained high even as the proportion of parents with a long history in the city declined. The proportion of boys sponsored by a tutor did rise over time, from five percent in the 1790s to ten percent in the 1830s, but it was fairly low in the immediate postwar period (5.4 percent).

The nature of sponsor obligations also changed. In the 1790s it was fairly common for the parents to explicitly announce liability for their son's actions (64 percent of contract contained some sort of statement to this effect-Table 5). Typically, they pledged to search for their son and return him to the master if he ran off (63 percent). Some also committed to pay damages of a particular sum if he breached the contract or stated more generally that they were liable for contract fulfillment or would ensure that their son fulfilled his obligations (24 percent of 1790s contracts contained one of these sponsor liability clauses). By the 1830s, explicit sponsor liability, and especially the pledge to run after a deserting son, was out of favor. Only 38 percent of contracts contained some form of explicit liability clause, and less than one-third of

expected productivity was initially much lower, but was expected to rise more over the term, than previous hires. This seems unlikely.

${ }^{58}$ In a few cases, when a minor was close to the age of majority (21) when he signed his contract, an adult sponsor was not present. 
these contracts contained a promise to search for a runaway apprentice. Furthermore, the biggest changes in the use of these clauses occurred between the war and postwar periods. ${ }^{59}$

Reassurance from a third party regarding the commitment of the apprentice and his family was also more prevalent as the nineteenth century progressed (these clauses were always uncommon, but much rarer in the 1790 s and 1800 s, see Table 5). ${ }^{60}$ Masters may have turned to (known) third parties for enforcement because they knew less about a boy's family. Hence masters were relying less on parental enforcement. Furthermore, when they did turn to parents they were much less likely to exact a commitment to chase after their fleeing son-a clause that arguably involved more risk (because parents could shirk) than a formal commitment to pay $£ 10$ in damages if their son did not fulfill his obligations.

Probationary periods also become more common in contracts signed in the $1830 \mathrm{~s}$ compared to the 1790 s. $^{61}$ The progression was not continuous, though; the incidence of probations declined until about 1815 , when it turned direction and climbed steadily thereafter. Because probationary periods were not common in contracts involving very young boys, the postwar rise in the age of new apprentices may account for the coincident growth in probation incidence. Even controlling for apprentice and master attributes, though, the trend in probation

\footnotetext{
${ }^{59}$ For example, 34 percent of contracts signed between 1812 and 1816 contained the 'run after' clause, compared with 14 percent of those signed between 1817 and 1821.

${ }^{60}$ For example, in the contract signed between John Harold (a shoemaker) and Helen Henry and her son James Home, Andrew Watson (carpenter) and Thomas Matthas (rope maker), "both of the city of Montreal do become bail and security toward Helen Henry in favour of John Harold in default of executing these presents on the part of the apprentice under pain of paying the master $£ 25$ each as damages." (29 December, 1842; contract \#7718; notary: J.A. Labadie).

${ }^{61}$ The length of the probationary period also grew over time.
} 
use was significantly steeper in the postwar era. ${ }^{62}$

It is difficult, if not impossible, to determine definitively whether the catalyst for these enforcement changes was large-shop employment practices (spilling over into the artisan shop) or a general decline in familiarity, due to population growth. Contracts involving large-shop $(P)$ masters were more likely to employ some of these clauses. For example, contracts with partnered-masters were less likely to include a runaway clause and were more likely to offer apprentices pay that rose during their term (Table 6). On the other hand, they did not tend to make use of probationary periods and actually signed up apprentices for terms that averaged three months longer (all else equal). Differences in the use of the clauses among $P$ and $N P$ masters did not, however, drive any of the results discussed above. In other words, the changes in compensation structure and enforcement also occurred in small $(N P)$ shops.

Large-shop employment practices could have sparked these postwar changes in artisan shops, but this seems unlikely at least within the context of apprentice contract data. Partneredmaster contracts constituted a very small proportion of contracts signed in the prewar era (Table 1). In addition, $P$ contracts signed between 1791 and 1803 were actually less likely to contain

${ }^{62}$ The robustness of this result depends marginally on the definition of postwar. The dependent variable is the incidence of probation:

\begin{tabular}{lcccccc}
\hline & \multicolumn{2}{c}{ Postwar (year>1815) } & \multicolumn{2}{c}{ Postwar (year>1816) } & \multicolumn{2}{c}{ Postwar (year>1817) } \\
\hline Age controls & NO & YES & NO & YES & \multicolumn{1}{c}{ NO } & YES \\
Trend & 0.0001 & 0.0017 & -0.0013 & -0.0003 & -0.0012 & -0.0005 \\
& $(0.0021)$ & $(0.0022)$ & $(0.0020)$ & $(0.0021)$ & $(0.0019)$ & $(0.0020)$ \\
Trend $\times$ Postwar & $0.0037 * *$ & 0.0019 & $0.0048 * * *$ & $0.0034 * *$ & $0.0046 * * *$ & $0.0035 * *$ \\
& $(0.0015)$ & $(0.0015)$ & $(0.0014)$ & $(0.0014)$ & $(0.0013)$ & $(0.0014)$ \\
\hline Postwar trend $^{\text {a }}$ & 0.0038 & 0.0036 & 0.0034 & 0.0031 & 0.0035 & 0.0030 \\
\hline
\end{tabular}

${ }^{\mathrm{a}}$ Sum of the trend and trend $\times$ postwar coefficients.

Unreported regressors: apprentice attributes (ethnicity, sign, age), master attributes (ethnicity, sign, partner, nayrhire) and trade dummy variables. The age controls are a series of dummy variables equal to one if the boy was less than 11, age(12-13), age(16-17), age(18-19), age(20-21), and greater than 21 (see appendix for definitions). The method of estimation is a probit, where the coefficients reported are maximum likelihood probit estimates of the change in probability of a one-unity change in the independent variable, evaluated at the means of the independent variables. 
cash than $N P$ contracts (17.5 percent for $P$ contracts, compared to 36.3 percent for $N P$ contracts). ${ }^{63}$ Given that negative demand shocks characterized the postwar decline, the weight of evidence concerning the initial postwar decline rests with the enforceability thesis. The negative supply shocks, rising shop size, and rapidly declining stock of contracts among both partneredmasters and NPs in the late-1820s and 1830s all suggest that potential apprentices first responded en masse to growing job opportunities in (high wage) factory-like settings after the initial postwar downturn.

\section{Conclusions}

In this paper I document and explore the timing of the decline in apprenticeship in North America, using a data set that consists of the population of craft contracts (involving boys) notarized in Montreal between 1791 and 1842. Quebec houses one of the only sources of systematic individual-level data on early apprenticeship within North America. These data mark the Napoleonic war as a pivotal event in the market for apprentice contracting. The stock of contracts, in both absolute and relative terms, began declining after the war. Masters that likely operated small shops (single-owner masters) contributed more to the initial downturn than largeshop $(P)$ masters. The stock of contracts involving masters operating in partnership did decline, but not until the 1830s. Linking masters in the contracts to city directories reveals that the decline was characterized by a rejection of apprentice contracting. The reduction in the contracting rate among masters was widespread, spanning trades and affecting both individual and partnered masters. The average number of contracts held per master also fell after the war. An analysis of the flows into and out of apprenticeship reveals that the stock fell after the war primarily because the rate at which apprentices completed their contracts began to exceed the

\footnotetext{
${ }^{63}$ In the next two periods (1804-16 and 1817-29), the incidence of cash was quite similar across $P$ and $N P$ contracts.
} 
rate at which new apprentices were hired. Around this time apprentices began serving shorter terms, and started their employment when they were older.

Two explanations for the decline of apprenticeship are explored in the paper: greater difficulty in enforcing long-term contracts and organizational changes that favored larger-scale production and unskilled labor. The catalyst for both hypotheses is arguably population growth, which is predicted to have made traditional apprentice contracts a riskier endeavor and fueled larger-scale production (where division of labor and greater use of unskilled children and women became the norm). These hypotheses offer different predictions regarding the market for apprentices and the nature of contracts, which are examined in the paper.

I find more support for the enforceability thesis during the initial postwar downturn. It was characterized by a reduction in apprentice demand that was particularly strong for young boys. Masters not only rejected these relatively risky contracts, but turned away from less formal enforcement techniques that tended to rely on familiarity between the boy's and the master's families. At this time masters also began investing less in apprentices. Instead of paying them the same each year-more than they were worth at the beginning of the term, and recouping this investment towards the end of the term - they began paying boys less and less initially, but more as their terms progressed. A steeper pay path likely followed an apprentice's expected future productivity more closely, and reduced the cost of premature breach or a bad match. This was a fundamental change in the nature of the traditional apprenticeship.

While it is quite possible that postwar population growth spurred a growing number of firms to adopt factory-like production, this transformation does not appear to have had a direct impact on the apprentice market until the late-1820s and 1830s. At this time, masters in partnership (firms that were more likely to have operated on a larger scale) started to increase their shop size. The average number of apprentices under contract rose substantially among these 
masters, as did the proportion of boys that were no longer housed under their master's roof. In addition, changes in pay and the stock of contracts suggest that the supply of older apprentices fell markedly in the late-1830s. Because there was no substantial change in access to education, the lure of higher paying unskilled (factory) jobs is the likeliest cause of this exodus.

These findings merit consideration by students of American apprenticeship. Many of the basic institutional features of apprenticeship were common to Quebec and the U.S.. For example, there were no guilds or restrictions on entry into crafts in either region. In addition, the Napoleonic war era is considered a turning point in American economic growth. ${ }^{64}$ The decline in apprenticeship may have progressed differently in the United States, but in the absence of American data any differences remain obscured.

This paper also offers a modest contribution to the literature on optimal systems of education and training. Europe held on to the apprentice system, while America embraced public education and thrived. ${ }^{65}$ In Quebec, public schooling did not supplant apprenticeship but emerged in the wake of its demise. Further study of this transition in each of these jurisdictions should lead to a better understanding of the relative merits of these two systems.

\footnotetext{
${ }^{64}$ Atack and Passell (1994: 8-10) discuss a variety of interpretations of early nineteenth-century growth.

${ }^{65}$ See Goldin and Katz (1997). For work on Germany's current apprentice system, see Pischke (1996).
} 


\section{References}

Adams, T.M. "Prices Paid by Vermont Farmers for Goods and Services and Received by them for Farm Products, 1790 - 1940; Wages of Vermont Farm Labor, 1780-1940." University of Vermont and State Agricultural College, Vermont Agricultural Experiment Station, Burlington, VT. Bulletin 507, February 1944. Burlington, Vermont: Free Press Printing Co., 1944.

Atack, Jeremy. "Economies of Scale and Efficiency Gains in the Rise of the Factory in America, 1820-1900." in Peter Kilby, editor, Quantity and Quiddity: Essays in U.S. Economic History. Conn.: Wesleyson University Press, 1987: 286-335.

Atack, Jeremy. "Industrial Structure and the Emergence of the Modern Industrial Corporation." In Robert Whaples and Dianne Betts, eds. Historical Perspectives on the American Economy: Selected Readings. New York: Cambridge University Press, 1995: 428-452.

Atack, Jeremy and Peter Passell. A New Economic View of American History: from Colonial Times to 1940, $2^{\text {nd }}$ edition. New York: W.W. Norton and Co., 1994.

Audet, Louis-Philippe. Le Système Scolaire de la Province de Québec. Volumes 1-4 Québec: Les Presses Universitaires Laval, 1952.

Audet, Pierre, “Apprenticeship in Early Nineteenth Century Montreal, 1790-1812.” M.A. Thesis, Concordia University, Montreal, 1975.

Baker, Michael and Dwayne Benjamin. "The Role of the Family in Immigrants' Labor-Market Activity: An Evaluation of Alternative Explanations." American Economic Review 87, no.4 (1997): 705-727.

Boulianne, Real. "The French Canadians and the Schools of the Royal Institution for the Advancement of Learning, 1820-1829." Histoire Sociale-Social History 5, no.10 (1972): 144164.

Brewer, Holly. "Republican Ideology and Apprenticeship Policy in Virginia: A Shift in Social Welfare Policy." Mimeo. Paper presented at the Social Sciences History Association Meetings, 1994.

Bridenbaugh, Carl. The Colonial Craftsman. New York: New York University Press, 1950.

Burgess, Joanne. "Work, Family and Community: Montreal Leather Craftsmen, 1790-1831." Ph.D. Dissertation, Université du Québec à Montréal, Montreal, 1987.

Burgess, Joanne. "The Growth of a Craft Labour Force: Montreal Leather Artisans, 1815-1831." Historical Papers (1988): 48-62.

Census of Canada, 1871. Volume 4: Censuses of Canada 1665 to 1871. Ottawa, 1876. 
Craig, Lee and Elizabeth Field-Hendrey. "Industrialization and the Earnings Gap: Regional and Sectoral Tests of the Goldin-Sokoloff Hypothesis." Explorations in Economic History 30 (Jan, 1993): 60-80.

Dechêne, Louise. Habitants and Merchants in Seventeenth-Century Montreal. Translated by Liana Vardi. Montreal: McGill-Queen's University Press, 1992.

Dickinson, John and Brian Young. A Short History of Quebec, $2^{\text {nd }}$ edition. Toronto: Copp Clark Pitman Ltd., 1993.

Doige, Thomas. An Alphabetical List of the Merchants, Traders, and Housekeepers Residing in Montreal. Montreal: James Lane, 1819.

Elbaum, Bernard. "Why Apprenticeship Persisted in Britain but not in the United States." Journal of Economic History 49, no.2 (1989): 337-349.

Epstein, Steven. "Craft Guilds, Apprenticeship, and Technological Change in Preindustrial Europe." Journal of Economic History 58, no.3 (1998): 684-713

Fyson, Donald. "Eating in the City: Diet and Provisioning in Early Nineteenth-Century Montreal.” MA Thesis, McGill University, 1989.

Galenson, David W. "Immigration and the Colonial Labor System: An Analysis of the Length of Indenture." Explorations in Economic History 14, no.3 (1977): 360-377.

Galenson, David W. "The Market Evaluation of Human Capital: The Case of Indentured Servitude." Journal of Political Economy 89, no.3 (1981a): 446-467.

Galenson, David W. White Servitude in Colonial America: An Economic Analysis. New York: Cambridge University Press, 1981b.

Galenson, David W. "The Rise and Fall of Indentured Servitude in the Americas." Journal of Economic History 44, no.1 (1984): 1-26.

Goldin, Claudia and Kenneth Sokoloff. "Women, Children, and Industrialization in the Early Republic: Evidence from the Manufacturing Censuses." Journal of Economic History 42, no.2 (1982): 741-74.

Goldin, Claudia and Kenneth Sokoloff. "The Relative Productivity Hypothesis of Industrialization: The American Case, 1820 to 1850." Quarterly Journal of Economics 99, no.3 (1984): 461-88.

Goldin, Claudia and Lawrence Katz. "Why the United States Led in Education: Lessons from Secondary School” NBER Working Paper, 1997. 
Grubb, Farley. "The Market for Indentured Immigrants: Evidence on the Efficiency of ForwardLabor Contracting in Philadelphia, 1745-1773." Journal of Economic History, 45, no.4 (1985): 855-868.

Grubb, Farley. "Does Bound Labor Have to be Coerced Labor? The Case of Colonial Immigrant Servitude Versus Craft Apprenticeship and Life-Cycle Servitude-in-Husbandry." Itinerario 21, no.1 (1997): 28-51.

Grubb, Farley. "The Disappearance of Organized Markets for European Immigrant Servants in the United States: Five Popular Explanations Reexamined." Social Science History 18, no.1 (1994a): 1-30.

Grubb, Farley. "The End of European Immigrant Servitude in the United States: An Economic Analysis of Market Collapse, 1772-1835." Journal of Economic History 54, no.4 (1994b): 794824.

Grubb, Farley. "The Auction of Redemptioner Servants, Philadelphia, 1771-1804: An Economic Analysis." Journal of Economic History 48, no.3 (1988): 583-603.

Grubb, Farley and Tony Stitt. "The Liverpool Emigrant Servant Trade and the Transition to Slave Labor in the Chesapeake, 1697-1707: Market Adjustments to War." Explorations in Economic History 31, no.3 (1994c): 376-405.

Hamilton, Gillian. "The Market for Montreal Apprentices: Contract Length and Information." Explorations in Economic History 33, no.4 (1996): 496-523.

Hamilton, Gillian. "Enforcement in Apprenticeship Contracts: Were Runaways a Serious Problem? Evidence from Montreal." Journal of Economic History 55, no. 3 (1995): 551-574.

Hanaway, Joseph and Richard Cruess. McGill Medicine Volume 1: The First Half Century, 18291885. Montreal: McGill-Queen's University Press, 1996.

Hansen, Hal. "Apprenticeship in Historical Perspective: Revising the Assumptions.” Chapter 2 of Caps and Gowns: Historical Reflections on the Institutions that Shaped Learning for and at Work in Germany and the United States, 1800-1945 Ph.D dissertation, University of WisconsinMadison, 1997.

Hardy, Jean-Pierre and David-Thiery Ruddel. Les Apprentis Artisans à Québec, 1660-1815. Montreal: Presses de l'Université du Québec 1977.

Holcomb, Priscilla and Daniel Jacoby. "Supplying the Plumbing Lines: New York Trade School Graduates from 1880 to 1920." Mimeo. Paper presented at the Social Sciences-History Association Conference, 1997.

Jacoby, Daniel. "The Transformation of Industrial Apprenticeship in the United States." Journal of Economic History 51, no.4 (1991a): 887-910. 
Jacoby, Daniel. "Legal Foundations of Human Capital Markets.” Industrial Relations 30, no.2 (1991b): 229-250.

James, John. "Structural Change in American Manufacturing, 1850-1890." Journal of Economic History 43, no.2 (1983): 433-59.

Lachance, Paul. "Kinship and Immigrant Apprentices' Chances in New Orleans, 1810-1840.” Mimeo, University of Ottawa, 1994.

Lewis, Frank. "Farm Settlement on the Canadian Prairies, 1898 to 1911." Journal of Economic History 41, no.3 (1981): 517-535.

MacKay, Robert. The Montreal Directory for 1843-4. Montreal: Lovell and Gibson, 1844.

Magnuson, Roger. A Brief History of Quebec Education: From New France to Parti Québécois. Montreal: Harvest House, 1980.

Margo, Robert and Georgia Villaflor. "The Growth of Wages in Antebellum America: New Evidence." Journal of Economic History 47, no.4 (1987): 873-895.

Montreal Gazette, various dates.

Moodie, Susanna. Roughing it in the Bush, $2^{\text {nd }}$ edition, 1852. Reprint issued by McClelland and Stewart, 1989.

Moogk, Peter. “The Craftsmen of New France.” Ph.D dissertation, University of Toronto, 1973.

Murray, John and Ruth Herndon. "Valuing Children in Early America: Compensation for Bound Child Labor in the Eighteenth Century." Mimeo, University of Toledo, 1999.

Pischke, Jörn-Steffen. “Continuous Training in Germany.” NBER Working Paper \#5829, 1996.

Poutanen, Mary Anne. “The Montreal Needle Trades during the Transition, 1820-42.” M.A. Thesis, McGill University, 1985.

Provincial Statutes of Lower Canada, various dates.

Quimby, Ian M.G. Apprenticeship in Colonial Philadelphia, New York: Norton Press, 1985.

Ramseyer, Mark. Odd Markets in Japanese History: Law and Economic Growth. New York: Cambridge University Press, 1996.

"Règles et Réglemens de Police pour La Cité et les Faubourgs de Montréal. Montréal: James Brown, 1821.

Rorabaugh, William J. The Craft Apprentice: From Franklin to the Machine Age in America. New York: Oxford University Press, 1986. 
Ruddel, David T. “Apprenticeship in Early Nineteenth Century Quebec, 1793-1815.” M.A. Thesis, University of Laval, Quebec City, 1969.

"Rules and Regulations of the Police for the City and Suburbs of Montreal." Montreal: Printed by James Lane, 1817.

Sokoloff, Kenneth. "Industrialization and the Growth of the Manufacturing Sector in the Northeast, 1820-1850.” Ph.D dissertation, Harvard University, 1982.

Sokoloff, Kenneth. "Was the Transition from the Artisanal Shop to the Non-mechanized Factory Associated with Gains in Efficiency? Evidence from the U.S. Manufactures Censuses of 1820 and 1850." Explorations in Economic History 21 (1984): 351-82.

Sokoloff, Kenneth and Georgia Villaflor. "The Market for Manufacturing Workers during Early Industrialization: The American Northeast, 1820 to 1860." In Claudia Goldin and Hugh Rockoff, eds. Strategic Factors in Nineteenth Century American Economic Growth: A Volume to Honor Robert W. Fogel. Chicago: University of Chicago Press, 1992: 29-65.

Steinfeld, Robert. The Invention of Free Labor. Chapel Hill: University of North Carolina Press, 1991.

Steinfeld, Robert and Stanley Engerman. "Labor-Free or Coerced? A Historical Reassessment of Differences and Similarities.” Mimeo, SUNY-Buffalo and University of Rochester, 1997.

Summers, L. and R. Clarke. "The Labor Scarcity Controversy Reconsidered.” Economic Journal 90 (1980): 129-139.

Sweeny, Robert. "Internal Dynamics and the International Cycle: Questions of the transition in Montreal, 1821-1828.” Ph.D. dissertation, McGill University, 1985.

U.S. Bureau of the Census. Historical Statistics of the United States, Colonial Times to 1970. Electronic edition edited by Susan B. Carter et al. [machine readable data file]. Cambridge: Cambridge University Press, 1997.

Williamson, Jeffrey and Peter Lindert. American Inequality: A Macroeconomic History. New York: Academic Press, 1980.

Wright, Gavin. "The Origins and Economic Significance of Free Labor in America” Mimeo. Stanford University, 1995. 
Figure 1: Average Annual Pay (V/T) over time: actual and hybrid values

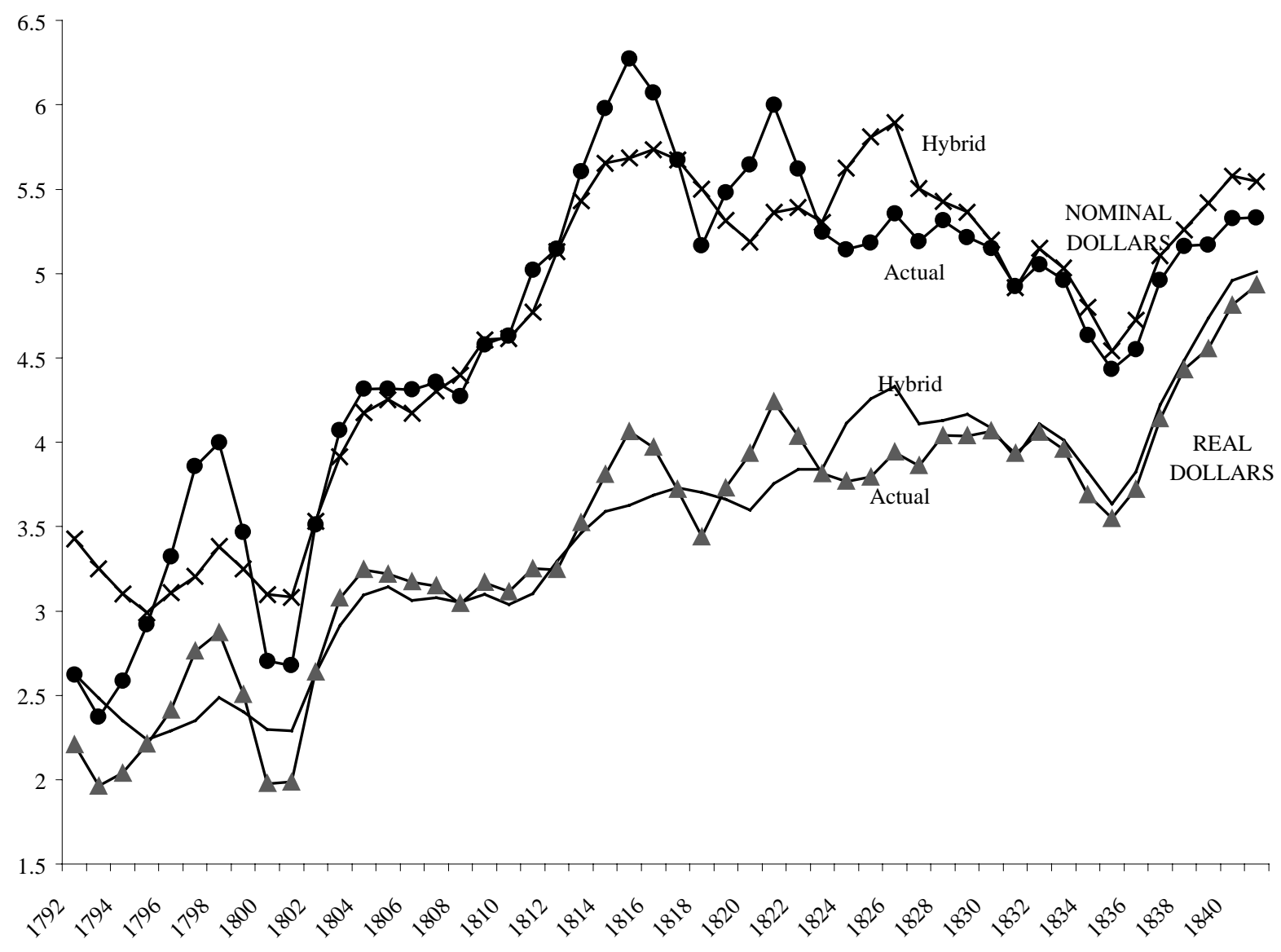

Notes: Actual: contains only actual values of $V / T$ and employs the sample of contracts with cash during the term, room or board, plus cash end pay or no end pay $(\mathrm{N}=1331)$. Hybrid: contains hybrid values of $V / T$. It takes on the actual values in the above cases, and predicted values otherwise $(\mathrm{N}=2749)$. See text. 
Figure 2: Apprentice stock

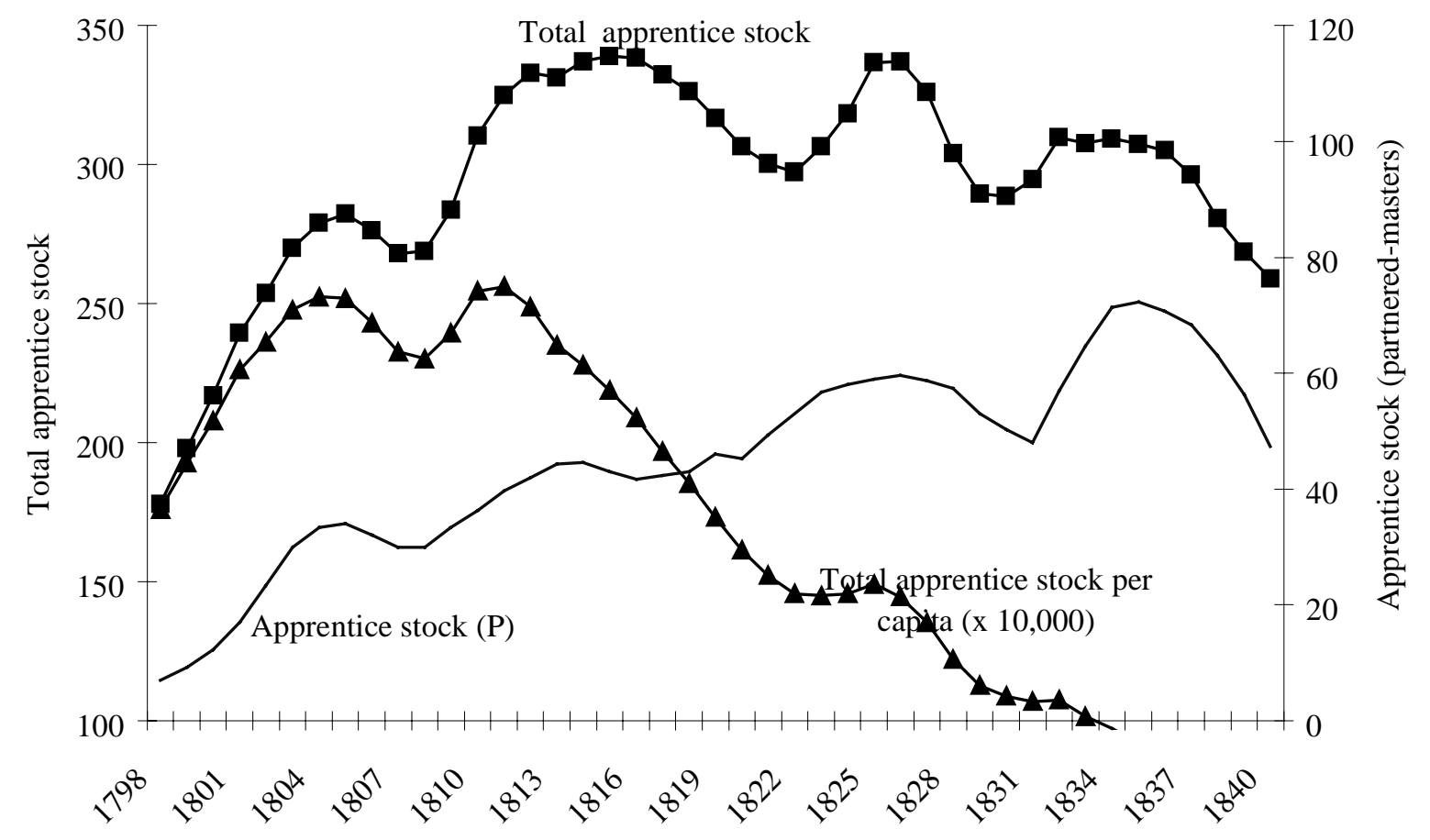

Notes: Three-year (centered) moving averages shown. $\mathrm{P}=$ partnered-masters. Annual population estimates are derived from linear interpolations using census counts in 1825, 1831, and 1842, as well as established estimates for $1810(12,000)$ and $1791(9,000)$. See Dechêne (1992) and Fyson (1989). 
Figure 3: The Contribution of Masters and Apprentices/Masters to the Apprentice Stock

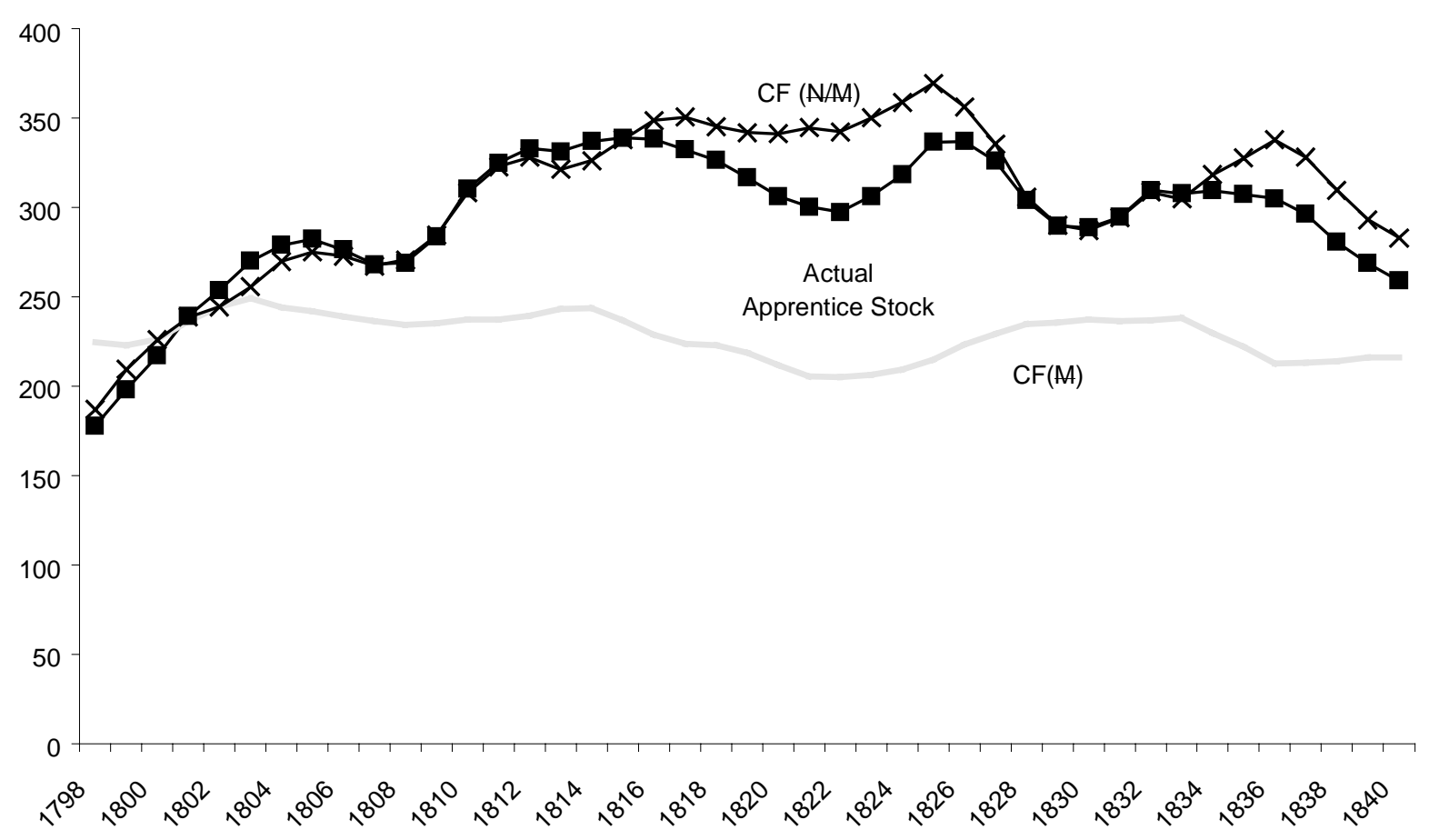

Notes: Three-year (centered) moving averages shown. $\mathrm{CF}=$ counterfactual. $\mathrm{N}=$ apprentice stock; $\mathrm{M}=$ stock of masters. $N_{t}=M_{t} / \frac{N_{t}}{M_{t}} . C F(\underline{M})=\bar{M}_{98-07} / \frac{N_{t}}{M_{t}} ; C F(\underline{N / M})=M_{t} /\left.\frac{\bar{N}}{M}\right|_{98-07}$, hence $C F(\underline{M})$ calculates the stock of contracts, holding the stock of masters constant at its average value between 1798 and 1807. $C F(\underline{N / M})$ is similarly defined, holding the number of contracts per master constant. 
Figure 4: The contribution of Entrances and Exits to the Growth Rate

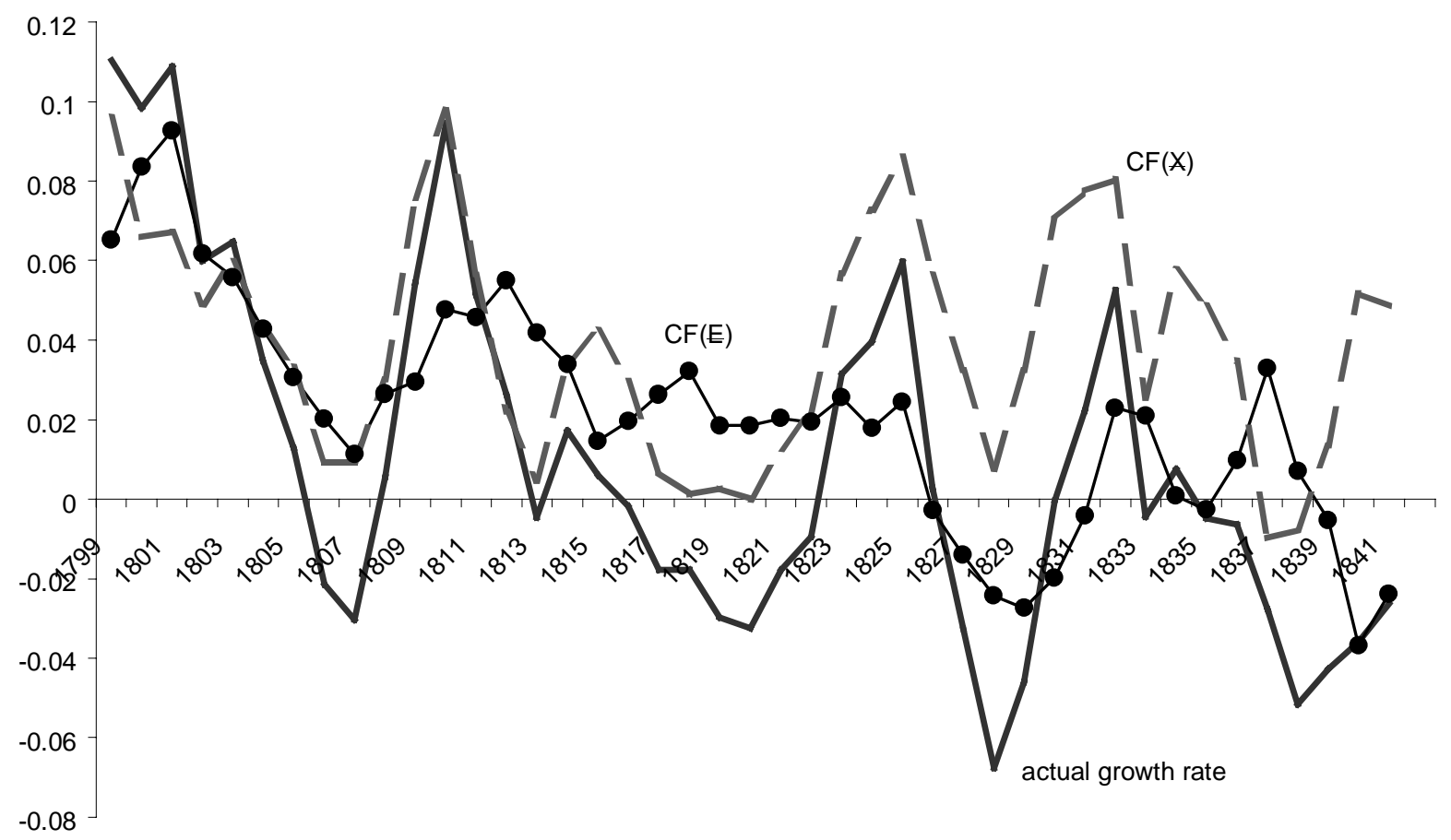

Notes: Three-year (centered) moving averages shown.

$\dot{N}_{t}=\left(N_{t}-N_{t-1}\right) / N_{t-1}=E_{t} / N_{t-1}-X_{t} / N_{t-1} C F(\underline{E})=\left.\left(\overline{E_{t} / N_{t-1}}\right)\right|_{98-07}-X_{t} / N_{t-1}$ (calculates a hypothetical growth rate, holding the entrance rate constant at its average value between 1798 and 1807). The second counterfactual holds the exit rate constant at its average value over 17981807: $C F(\underline{X})=E_{t} / N_{t-1}-\left.\left(\overline{X_{t} / N_{t-1}}\right)\right|_{98-07}$. 
Figure 5: Average Starting Age, Duration, and Tenure of New Contracts

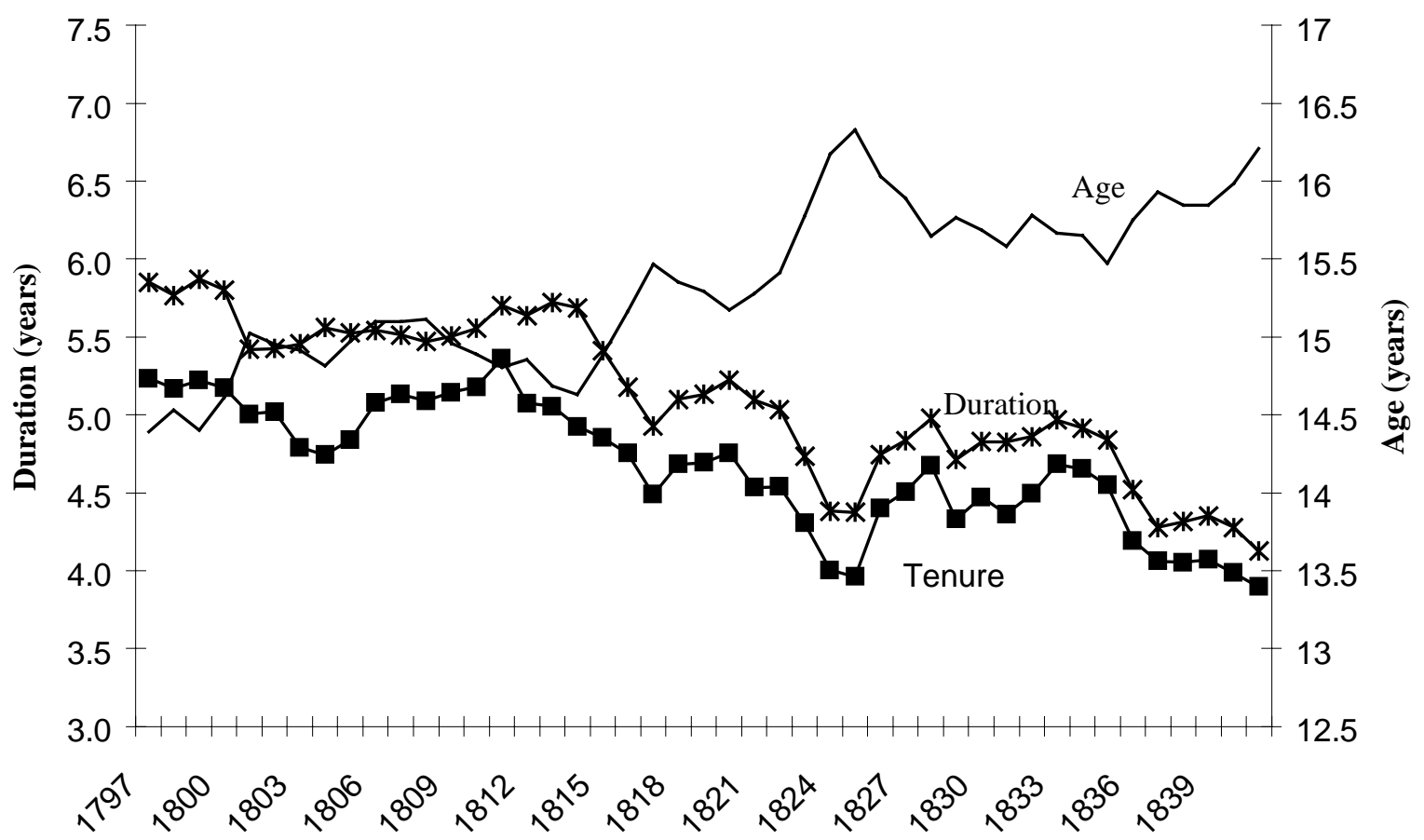

Notes: Three-year (centered) moving averages shown. Tenure is defined as the duration of apprenticeship served - the length stipulated in the contract if it was not annulled, or the duration served if it was annulled. Age refers to the average age of apprentices at the time they signed their contracts. Duration includes the contract and probation periods (where relevant). 
Figure 6a: The Market for Apprentices-The Enforceability Hypothesis



Figure 6b: The Market for Apprentices-The Goldin-Sokoloff Hypothesis



Old Apprentices

$W_{o}$




Figure 7: Total real pay, by age and year (regression coefficients)



Notes: The OLS regression is $V_{R}=a_{i} A_{i}+b_{j} M_{j}+c_{k} T_{R A D E S_{k}}+d_{l} Y E A R_{l}+g_{l} Y E A R_{l} \times A G E_{<15}$, where $A_{i}=$ a vector of $i$ apprentice attributes $\left(\mathrm{AGE}_{<15}=\right.$ dummy variable equal to 1 if the boy is less than 15 when he began his contract, French last name, Sign); $M_{j}=$ a vector of $j$ master attributes (PARTNER, French last name, Sign, NAYRHIRE), TRADES ${ }_{k}$ is the vector of $k$ trade dummy variables and $Y E A R_{l}=l$ individual year effects marking the year the contract was signed. Blacksmith/coachmakers is the omitted trade, and years 1791-5 are omitted. The dependent variable is defined over all contracts (it takes on the predicted values for contracts without cash). Three-year (centered) moving averages of the estimated coefficients from the individual year dummy variables ( $d_{l}$ 's and $g_{l}$ 's) are shown. Note that the $a_{i}$ coefficient on $\mathrm{AGE}_{<15}(+2.44$, significant at the 5 percent level) has not been added to the interaction coefficients. 
Figure 8: Duration and Average Annual Pay, by age and year (regression coefficients)

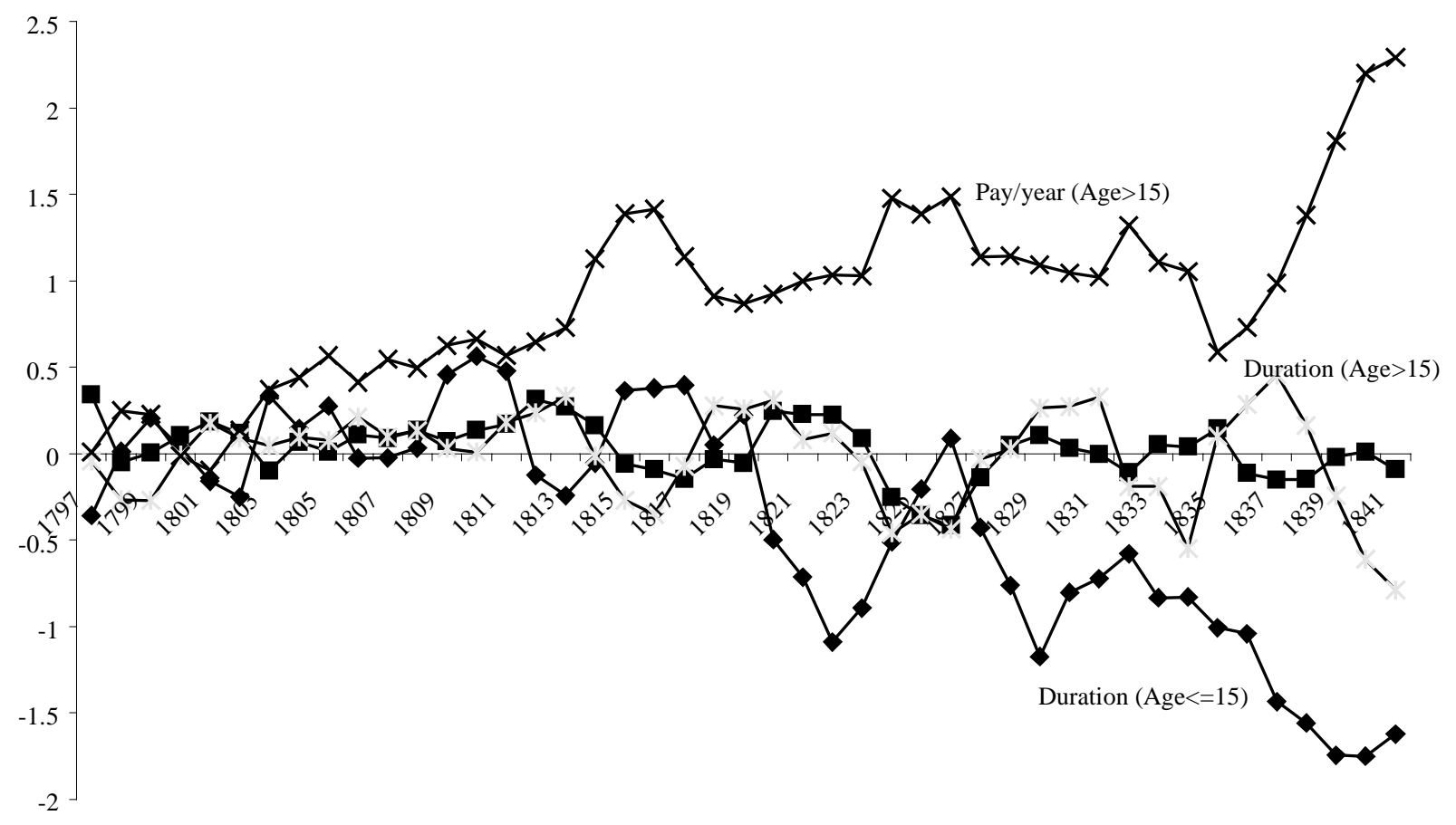

Notes: The explanatory variables for each regression are as shown in Figure 7:

$\left(a_{i} A_{i}+b_{j} M_{j}+c_{k} T_{R A D E S_{k}}+d_{l} Y E A R_{l}+g_{l} Y E A R_{l} \times A G E_{<15}\right)$, where the dependent variable is duration in one case, and average annual real pay in the other (defined over all contracts, it takes on predicted values where required). Three-year (centered) moving averages of the OLS coefficient estimates from the individual year dummy variables ( $d_{l}$ 's and $g_{l}$ 's) are shown. The coefficient on $\mathrm{AGE}_{<15}$ is +2.77 in the duration regression and -0.91 in the average annual pay regression (both significant at the one percent level). The unlabeled series is for Pay/year (Age $\leq 15)$. 
Figure 9: Contracts with Cash, Room, and Board: Average Annual Pay and First Year Pay

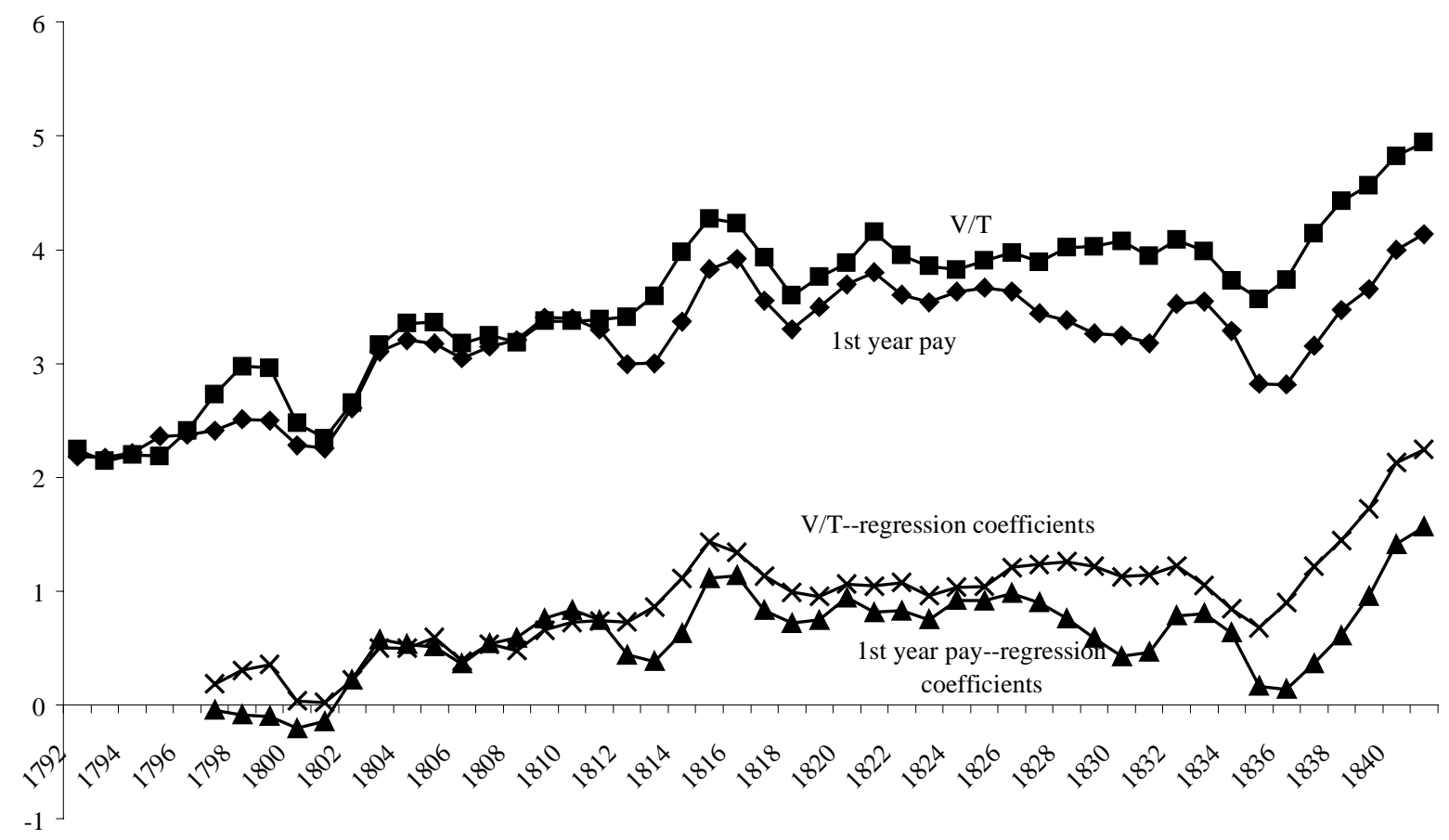

Notes: The OLS regressions are $V_{R} / T ; V_{R, 1}=a_{i} A_{i}+b_{j} M_{j}+c_{k} T R A D E S_{k}+d_{l} Y E A R_{l}$, where $A_{i}=\mathrm{a}$ vector of $i$ apprentice attributes (Age, French last name, Sign, where Age is specified as a series of two-year dummy variables, see appendix); $M_{j}=$ a vector of $j$ master attributes (partner,

French last name, Sign, NAYRHIRE), TRADES ${ }_{k}$ is the vector of $k$ trade dummy variables and $Y E A R_{l}=l$ individual year effects marking the year the contract was signed. The omitted category is a blacksmith/coachmaker hiring an apprentice aged 14-15 in years 1791-5. The dependent variable is $V_{R} / T$ in one case and first year pay $\left(V_{R, 1}\right)$ in the other. 


\begin{tabular}{|c|c|}
\hline Variable & Definition \\
\hline Trend & Equals 1 to 42 for years 1791 to 1842 respectively. \\
\hline Trades: & Dummy variables for master's trade. \\
\hline Baker & 1 if a baker, confectioner, biscuit or pastry maker. \\
\hline Tailor & 1 if a tailor, couturier (sewer), or merchant tailor. \\
\hline Hatter/furrier & 1 if a furrier, hat manufacturer, hatter or merchant hatter. \\
\hline Carpenter & $\begin{array}{l}1 \text { if a joiner, carpenter, menuisier, builder, ship builder, plasterer ( } \& \\
\text { carpenter), or millwright. }\end{array}$ \\
\hline Furniture maker & $\begin{array}{l}1 \text { if a cabinet maker ( } \& \text { upholsterer), meublier, piano forte maker, } \\
\text { turner, turner of block and pump maker, carver ( } \& \text { gilder), or chair } \\
\text { maker. }\end{array}$ \\
\hline Blacksmith & $\begin{array}{l}1 \text { if a blacksmith, edge-tool maker, gunsmith, tinsmith, tin plate maker, } \\
\text { tin ware manufacturer, cutler, founder (iron \& brass) or carriage or } \\
\text { coach maker }\end{array}$ \\
\hline Shoemaker & 1 if a shoe or boot maker. \\
\hline Manufacturer & $\begin{array}{l}1 \text { if a brush, soap, candle, or comb maker, tobacconist, rope } \\
\text { manufacturer, or wheel wright. }\end{array}$ \\
\hline Cooper & 1 if a cooper or cooper and distiller. \\
\hline Printer/bookbinder & 1 if a book binder, book seller and stationer, paper maker or printer. \\
\hline Mason & 1 if a mason, brick maker, or brick layer. \\
\hline Butcher & 1 if a butcher, pork butcher, or sausage maker. \\
\hline Saddler/tanner & 1 if a saddler, tanner, whip maker or currier. \\
\hline Jeweler & $\begin{array}{l}1 \text { if a clock or watch maker or repairer, orfevre, silver smith, or } \\
\text { (copper plate) engraver. }\end{array}$ \\
\hline Miscellaneous trades & $\begin{array}{l}1 \text { if a farmer, cultivateur, yeoman, gardener, dyer and scourer, barber } \\
\text { and wig setter, mariner, miller, brewer, painter, glazier, gilder, potter, } \\
\text { or unknown. }\end{array}$ \\
\hline \multicolumn{2}{|l|}{ Apprentice attributes: } \\
\hline Age & Age of apprentice at the time the contract was drawn up (in years). \\
\hline Age $\leq 11 ; \operatorname{Age}(12-13)$ & 1 if apprentice's age $\leq 11 ; 1$ if $11<$ age $\leq 13$. \\
\hline $\operatorname{Age}(14-15) ; \operatorname{Age}(16-17)$ & 1 if $13<$ age $\leq 15 ; 1$ if $15<$ age $\leq 17$ \\
\hline Age(18-19); Age(20-21) & 1 if $17<$ age $\leq 19 ; 1$ if $19<$ age $\leq 21$. \\
\hline Age $>21$ & 1 if age $>21$. \\
\hline French last name & 1 if his last name was French. \\
\hline Signed & 1 if he signed his name. \\
\hline \multicolumn{2}{|l|}{ Master attributes: } \\
\hline Partnership & 1 if the master had a partner or company (e.g., Smith and Co.) \\
\hline French last name & 1 if his last name was French. \\
\hline Signed & 1 if he signed his name. \\
\hline NAYRHIRE & $\begin{array}{l}\text { (Number of Apprentices in YeaR HIREd) equals the number of active } \\
\text { apprentice contracts a master was carrying in the year a new contract } \\
\text { was signed (equals } 1 \text { if there were no other contracts). }\end{array}$ \\
\hline \multicolumn{2}{|l|}{ Contract terms: } \\
\hline Probation (incidence) & 1 if the term began before the contract date. \\
\hline Probation (duration) & Length of probation period, in years. \\
\hline Duration of apprenticeship & Length of contract plus length of probation. \\
\hline
\end{tabular}


Table 1: Contract Characteristics (averages, in percent)

\begin{tabular}{|c|c|c|c|c|c|}
\hline & All & 1791-1803 & 1804-16 & $1817-29$ & $1830-42$ \\
\hline Teach & 92.55 & 96.89 & 96.47 & 86.00 & 93.29 \\
\hline \multirow[t]{2}{*}{ Duration of apprenticeship (years) } & 5.08 & 5.50 & 5.54 & 4.82 & 4.59 \\
\hline & $(2.16)$ & $(2.29)$ & $(2.44)$ & $(2.03)$ & $(1.70)$ \\
\hline \multicolumn{6}{|l|}{ Apprentice attributes: } \\
\hline Signed & 36.85 & 28.46 & 28.44 & 39.25 & 48.59 \\
\hline French last name & 57.18 & 67.00 & 65.69 & 53.00 & 46.17 \\
\hline \multirow[t]{2}{*}{ Age (years) } & 15.37 & 14.92 & 14.90 & 15.73 & 15.79 \\
\hline & $(2.34)$ & $(2.48)$ & $(2.41)$ & $(2.24)$ & $(2.11)$ \\
\hline \multicolumn{6}{|l|}{ Master attributes: } \\
\hline Signed & 75.37 & 79.64 & 70.36 & 73.83 & 79.06 \\
\hline French last name & 46.49 & 57.11 & 53.40 & 40.45 & 38.39 \\
\hline Partnership (stated in contract) & 6.91 & 2.17 & 4.54 & 9.21 & 10.20 \\
\hline Partnership (master ever in one) & 14.15 & 7.91 & 11.21 & 17.36 & 18.12 \\
\hline NAYRHIRE & 2.53 & 2.02 & 2.31 & 2.94 & 2.70 \\
\hline \multicolumn{6}{|l|}{ Trades: } \\
\hline Furniture/carpenter & 16.59 & 21.15 & 15.89 & 18.56 & 12.21 \\
\hline Shoemaker & 16.08 & 11.66 & 16.96 & 16.96 & 17.32 \\
\hline Blacksmith/coachmaker & 12.84 & 15.22 & 9.35 & 11.35 & 16.24 \\
\hline Cooper & 9.49 & 13.83 & 12.02 & 8.54 & 4.97 \\
\hline Tailor & 7.28 & 7.11 & 5.87 & 8.28 & 7.79 \\
\hline Saddler/tanner & 6.15 & 5.34 & 6.81 & 4.94 & 7.25 \\
\hline Baker & 5.13 & 2.17 & 5.74 & 4.94 & 6.71 \\
\hline Miscellaneous & 4.77 & 3.56 & 4.14 & 5.87 & 5.10 \\
\hline Printer/bookbinder & 4.55 & 0.20 & 4.27 & 6.14 & 6.17 \\
\hline Mason & 3.97 & 1.98 & 6.94 & 2.40 & 3.89 \\
\hline Hatter/furrier & 3.86 & 5.93 & 5.61 & 2.54 & 2.01 \\
\hline Jeweller & 2.55 & 4.94 & 3.47 & 1.47 & 1.07 \\
\hline Butcher & 2.55 & 3.36 & 2.27 & 3.07 & 1.74 \\
\hline Manufacturer & 2.47 & 0.59 & 0.13 & 2.54 & 6.04 \\
\hline Unknown & 1.75 & 2.96 & 0.53 & 2.40 & 1.48 \\
\hline Total & 100 & 100 & 100 & 100 & 100 \\
\hline $\mathrm{N}$ & 2749 & 506 & 749 & 749 & 745 \\
\hline
\end{tabular}

Notes: Standard deviation in parentheses. Teach $=1$ if the master promised to teach the apprentice his trade (in whole or in part), 0 otherwise. Coding on the teach clause is incomplete (its presence or absence was not recorded for all contracts). The number of observations for the teach clause are 2457 (all years), 354 (1790s), 651 (1800s), 707 (1820s), 745 (1830s). See appendix for definitions. Source: ANQM (Archives Nationales du Québec de Montréal). 
Table 2: Aspects of Pay

\begin{tabular}{|c|c|c|c|c|c|c|c|}
\hline \multirow[t]{2}{*}{ Ro } & Variable & Sample ${ }^{\text {a }}$ & All & 1791-03 & $1804-16$ & $1817-29$ & $1830-42$ \\
\hline & \multicolumn{7}{|c|}{ Percent of Contracts with... } \\
\hline 1 & Room (R) & All & 89.99 & 91.30 & 94.66 & 90.75 & 83.62 \\
\hline 2 & Board (B) & All & 92.43 & 98.02 & 96.80 & 91.15 & 85.50 \\
\hline 3 & Clothing & All & 40.72 & 59.49 & 51.94 & 36.50 & 20.94 \\
\hline 4 & Washing & All & 53.97 & 54.74 & 62.08 & 50.67 & 48.59 \\
\hline 5 & Mending & All & 29.62 & 25.89 & 40.05 & 27.41 & 23.89 \\
\hline 6 & End pay (EP) & All & 33.25 & 60.08 & 49.27 & 21.23 & 11.01 \\
\hline 7 & In-kind EP & EP & 78.42 & 88.49 & 85.64 & 62.89 & 39.02 \\
\hline 8 & No room or board (No RB) & All & 6.96 & 1.38 & 3.07 & 7.52 & 14.09 \\
\hline 9 & No cash & All & 41.69 & 65.22 & 53.67 & 37.12 & 18.26 \\
\hline 10 & Sample share estimated & All & 51.58 & 69.17 & 61.95 & 47.53 & 33.29 \\
\hline \multicolumn{8}{|c|}{ Actual and Estimated Cash Payments (average $£$ ) } \\
\hline \multicolumn{8}{|c|}{ Step I } \\
\hline 11 & Actual cash EP & Cash EP & 10.90 & 7.06 & 9.53 & 14.52 & 10.76 \\
\hline 12 & Predicted cash EP & In-kind EP & 8.31 & 6.98 & 9.16 & 9.00 & 9.05 \\
\hline 13 & Hybrid I: cash EP & EP & 8.86 & 6.99 & 9.21 & 11.02 & 10.09 \\
\hline \multicolumn{8}{|c|}{ Step II } \\
\hline 14 & $V_{N} / T$ (uses Hybrid I for EP) & $\mathrm{RB}$ & 3.13 & 1.74 & 2.94 & 3.48 & 4.05 \\
\hline 15 & $V_{N} / T$ (uses Hybrid I for EP) & No $R B$ & 21.06 & 3.41 & 18.32 & 24.18 & 21.17 \\
\hline 16 & Predicted $V_{N} / T$ & No RB & 5.71 & 2.40 & 4.54 & 5.91 & 6.08 \\
\hline 17 & Hybrid II: $V_{N} / T$ & All & 3.34 & 1.75 & 2.99 & 3.78 & 4.34 \\
\hline \multicolumn{8}{|c|}{ Step III } \\
\hline 18 & $V_{N} / T$ (Hybrid II) & Cash & 5.14 & 3.41 & 5.27 & 5.65 & 5.17 \\
\hline 19 & $V_{N} / T$ (Hybrid II) & No cash & 0.83 & 0.87 & 1.03 & 0.61 & 0.63 \\
\hline 20 & Predicted $V_{N} / T$ & No cash & 4.41 & 3.25 & 4.58 & 5.35 & 4.81 \\
\hline 21 & (Final) Hybrid: $V_{N} / T$ & All & 4.84 & 3.31 & 5.27 & 5.65 & 5.17 \\
\hline 22 & Hybrid: $V_{R} / T$ & All & 3.58 & 2.47 & 3.27 & 3.99 & 4.25 \\
\hline 23 & Hybrid: $V_{R}$ & All & 17.08 & 13.04 & 17.10 & 18.29 & 18.57 \\
\hline 24 & $\mathrm{~N}^{\sim}$ & All & 2749 & 506 & 749 & 749 & 745 \\
\hline
\end{tabular}

Notes: ${ }^{\text {a }}$ The Sample column identifies the relevant sample: $A l l=$ all contracts $(\mathrm{N}=2749) ; E P=$ contracts with end payments $(\mathrm{N}=914)$; Cash $E P=$ contracts with cash end payments $(\mathrm{N}=197) ; R B=$ contracts with room or board. Room, Board, Washing, Mending, Clothing, $\mathrm{EP}=1$ if the master was to provide the respective item, 0 otherwise. All currency is in Halifax currency (pounds). $V_{R} / T=$ actual average annual real pay, $V_{R}=$ total real pay.

Sample share estimated is the proportion of contracts that do not fall into the following category: contracts with cash, room or board, cash end pay or no end pay.

The hybrid values constitute a weighted average of the predicted and actual average $V / T$ values (see text for explanation). Hybrid I (row 13): weighted average of rows 11 and 12; Hybrid II (row 17): weighted average of rows 14 and 16; Hybrid (row 21): weighted average of rows 18 and 20.

Some aspects of in-kind pay were unclear in a few contracts. The sample size on room and board is 2746; it is 2742 for washing, 2748 for mending and clothing. These contracts were signed in the 1820s. Source: ANQM. 
Table 3: City Directories: Proportion of People Signing Apprentice Contracts (as masters)

\begin{tabular}{lccccc}
\hline & \multicolumn{2}{c}{1819 Directory } & & \multicolumn{2}{c}{1843 Directory } \\
\cline { 2 - 3 } \cline { 5 - 6 } & Number & Percent & & Number & Percent \\
& Listed in & Signing & & Listed in & signing \\
& Directory & contracts* & & Directory & contracts \\
\hline Total & $\mathbf{5 5 6}$ & $\mathbf{2 7 . 1 6}$ & & $\mathbf{1 7 7 7}$ & $\mathbf{1 5 . 5 9}$ \\
Total per capita (percent) & $\mathbf{3 . 0 3}$ & & $\mathbf{3 . 9 0}$ & \\
\multicolumn{1}{c}{ Total-partner } & $\mathbf{2 7}$ & $\mathbf{6 6 . 6 7}$ & & $\mathbf{4 8}$ & $\mathbf{3 7 . 5 0}$ \\
Total-non-partner & $\mathbf{5 2 9}$ & $\mathbf{2 5 . 1 4}$ & & $\mathbf{1 7 2 9}$ & $\mathbf{1 4 . 9 8}$ \\
Furniture/carpenter & 141 & 22.7 & & 626 & 8.31 \\
Shoemaker & 72 & 19.44 & & 260 & 23.46 \\
Blacksmith/coachmakers & 72 & 30.56 & & 254 & 14.96 \\
Cooper & 29 & 44.83 & & 75 & 25.33 \\
Tailor & 49 & 26.53 & & 124 & 21.77 \\
Saddler/tanner & 26 & 19.23 & & 63 & 20.64 \\
Baker & 54 & 33.33 & & 98 & 20.41 \\
Printer/bookbinder & 15 & 46.67 & & 57 & 21.05 \\
Hatters/furrier & 18 & 33.33 & & 34 & 14.71 \\
Jeweler & 22 & 31.82 & & 37 & 27.03 \\
Butcher & 40 & 25 & 80 & 8.75 \\
Manufacturer & 18 & 22.22 & 69 & 18.84 \\
\hline Notes: Names of individuals listed as practicing the relevant trade in the directories have been linked to masters' \\
names in the contract database.
\end{tabular}


Table 4: Stock and Flow of Apprentices, select years

\begin{tabular}{rrrrrrrrr}
\hline Year & $N_{t}$ & $E_{t}$ & $X_{t}$ & $\dot{N}_{t}$ & $E_{t} / N_{t-1}$ & $X_{t} / N_{t-1}$ & $M_{t}$ & $N_{t} / M_{t}$ \\
\hline 1798 & 180 & 43 & 29 & 0.084 & 0.259 & 0.175 & 130 & 1.385 \\
1802 & 255 & 51 & 33 & 0.076 & 0.215 & 0.139 & 163 & 1.564 \\
1806 & 279 & 56 & 59 & -0.011 & 0.199 & 0.209 & 186 & 1.500 \\
1810 & 312 & 75 & 45 & 0.106 & 0.266 & 0.160 & 210 & 1.486 \\
1814 & 332 & 60 & 64 & -0.012 & 0.179 & 0.190 & 216 & 1.537 \\
1818 & 325 & 52 & 57 & -0.015 & 0.158 & 0.173 & 237 & 1.371 \\
1822 & 306 & 61 & 49 & 0.041 & 0.207 & 0.167 & 241 & 1.270 \\
1826 & 347 & 73 & 68 & 0.015 & 0.213 & 0.199 & 248 & 1.399 \\
1830 & 279 & 67 & 69 & -0.007 & 0.238 & 0.246 & 193 & 1.446 \\
1834 & 300 & 43 & 67 & -0.074 & 0.133 & 0.207 & 202 & 1.485 \\
1838 & 278 & 36 & 51 & -0.051 & 0.123 & 0.174 & 209 & 1.330 \\
1842 & 250 & 54 & 53 & 0.004 & 0.217 & 0.213 & 184 & 1.359 \\
\hline
\end{tabular}

Notes: $N_{t}$ is the stock of active apprentice contracts in year $t . \quad \dot{N}_{t}=\left(N_{t}-N_{t-1}\right) / N_{t-1} . \quad E_{t}$ is the number of contracts signed in year $t$. The number of exits in year $t$ is defined as $X_{t}=N_{t-1}-N_{t}+E_{t}$. The entrance rate is $E_{t+1} / N_{t} ; X_{t+1} / N_{t}$ is the exit rate, and $M_{t}$ is the stock of masters with active contracts in year $t$. 
Table 5: Contract Enforcement (averages, in percent)

\begin{tabular}{|c|c|c|c|c|c|}
\hline & All years & $1791-03$ & $1804-16$ & $1817-29$ & $1830-42$ \\
\hline Sponsor & 98.29 & 96.64 & 99.60 & 98.40 & 97.99 \\
\hline Tutor $^{\mathrm{a}}$ & 7.18 & 5.12 & 8.18 & 5.43 & 9.32 \\
\hline Parent $^{\text {a }}$ & 88.42 & 90.59 & 86.86 & 91.72 & 85.21 \\
\hline Other relative $^{\mathrm{a}}$ & 4.40 & 4.29 & 4.96 & 2.85 & 5.48 \\
\hline Total $^{\mathrm{a}}$ & 100 & 100 & 100 & 100 & 100 \\
\hline Sponsor liability ${ }^{a}$ & 27.67 & 24.18 & 20.94 & 31.75 & 32.74 \\
\hline Sponsor runs after apprentice ${ }^{a}$ & 32.44 & 62.91 & 47.79 & 19.13 & 9.86 \\
\hline Sponsor liability OR runs after boy ${ }^{a}$ & 47.52 & 64.42 & 53.35 & 39.48 & 38.36 \\
\hline Third party liable ${ }^{a}$ & 2.07 & 0.40 & 1.07 & 1.87 & 4.43 \\
\hline Probation (incidence) & 42.68 & 39.28 & 34.84 & 42.51 & 52.37 \\
\hline \multirow[t]{2}{*}{ Probation (duration, in years) ${ }^{b}$} & 0.30 & 0.27 & 0.25 & 0.31 & 0.34 \\
\hline & $(0.44)$ & $(0.39)$ & $(0.38)$ & $(0.46)$ & $(0.49)$ \\
\hline Constant pay (excluding EP) & 71.43 & 93.07 & 83.71 & 68.62 & 47.25 \\
\hline Constant cash pay (excluding EP) & 51.19 & 81.14 & 64.84 & 50.11 & 35.63 \\
\hline Constant pay ${ }^{c^{x}}$ & 40.45 & 33.79 & 36.58 & 51.27 & 37.99 \\
\hline Annulment & 13.31 & 17.19 & 14.29 & 13.89 & 9.13 \\
\hline $\mathrm{N}$ & 2749 & 506 & 749 & 749 & 745 \\
\hline $\mathrm{N}$ (incidence of probation) ${ }^{\mathrm{d}}$ & 2467 & 471 & 640 & 661 & 695 \\
\hline
\end{tabular}

Standard deviations in parentheses. $\mathrm{EP}=$ end payment. All variables except probation (duration), are dummy variables equal to 1 if the clause or attribute appeared in the contract, 0 otherwise. See text for definitions.

${ }^{a}$ Conditional on having a sponsor. Constant pay not known in one case (first period).

${ }^{\mathrm{b}}$ Conditional on having a probation

${ }^{\mathrm{c}}$ Constant pay equals 1 if the apprentice received either in-kind pay only (with no reference to more or better clothing or board as the term progressed) and/or cash which did not increase during the term. Hence unless the contract stated otherwise, the value of in-kind pay is assumed to have been constant over the duration of a contract. Constant pay (excluding end period) considers pay during the term only (exclusive of end payments). Constant pay considers pay during the term and end payments (equals one if pay constant during term and there was no end payment).

${ }^{\mathrm{d}}$ It is not possible to determine whether there was a probation in all contracts (if, for example, the contract did not specify when the term began). For the purposes of calculating term length, the start date is assumed to coincide with the contract date in these cases. Source: ANQM. 
Table 6: Big-firm Effects

\begin{tabular}{|c|c|c|c|c|c|}
\hline Dep.var.: & Duration & Probation & Runaway & End Payment & Rising Pay \\
\hline Partner & $0.264 \quad(0.076) * * *$ & $0.031 \quad(0.033)$ & $-0.066(0.030) * *$ & $0.012(0.031)$ & $0.016 \quad(0.049)$ \\
\hline NAYRHIRE & $0.026(0.007) * * *$ & $-0.005(0.003) *$ & $0.002(0.003)$ & $0.009(0.002) * * *$ & $0.035(0.011) * * *$ \\
\hline $1798-1802$ & $-0.124(0.117)$ & $0.023 \quad(0.0$ & $0.099 \quad(0.0$ & $-0.045(0$. & $0.251 \quad(0.092) * *$ \\
\hline $1803-1807$ & $-0.040 \quad(0.117)$ & $-0.057 \quad(0.050)$ & $-0.057 \quad(0.036)$ & $-0.138 \quad(0.032) * * *$ & $0.252(0.087) * * *$ \\
\hline $1808-1812$ & $0.041 \quad(0.111)$ & $0.014 \quad(0.049)$ & $-0.057 \quad(0.035)$ & $-0.111(0.033) * * *$ & $0.291(0.082) * * *$ \\
\hline $1813-1817$ & $-0.088 \quad(0.112)$ & $-0.079 \quad(0.047)$ & $-0.140 \quad(0.027) * * *$ & $-0.193(0.026) * * *$ & $0.347(0.075) * * *$ \\
\hline $1818-1822$ & $-0.188 \quad(0.116)$ & $-0.003(0.051)$ & $-0.209 \quad(0.020) * * *$ & $-0.261 \quad(0.019) * * *$ & $0.406(0.066) * * *$ \\
\hline $1823-1827$ & $-0.236(0.110) * *$ & $0.025 \quad(0.0$ & $-0.250 \quad(0.017) * * *$ & $-0.317(0.016) * * *$ & $0.453(0.061) * * *$ \\
\hline $1828-1832$ & $-0.336(0.111) * * *$ & $0.090(0.049) *$ & $-0.241 \quad(0.018) * * *$ & $-0.323(0.014) * * *$ & $0.534(0.050) * * *$ \\
\hline $1833-1837$ & $-0.437 \quad(0.113) * * *$ & $0.124(0.050) * *$ & $-0.277 \quad(0.014) * * *$ & $-0.315(0.015) * * *$ & $0.478 \quad(0.057) * * *$ \\
\hline $1838-1842$ & $-0.540(0.116) * * *$ & $0.207 \quad(0.049) * * *$ & $-0.300 \quad(0.012) * * *$ & $-0.338(0.012) * * *$ & $0.536(0.046) * * *$ \\
\hline $\mathrm{N}^{\mathrm{a}}$ & 2467 & 2467 & 2698 & 2749 & 1425 \\
\hline R-squared ${ }^{b}$ & 0.6693 & 0.1085 & 0.3177 & 0.2479 & 0.1602 \\
\hline
\end{tabular}

Notes: The dependent variables: duration is in years; the rest are dummy variables equal to one if the contract included the clause. Runaway refers to the clause where the sponsor (parent) commits to chase and return a runaway apprentice to the master.

Method of estimation is OLS for the duration regression, probit otherwise. The probit coefficents reported are maximum likelihood estimates of the change in probability of a one-unity change in the independent variable, evaluated at the means of the independent variables. Standard errors are in parentheses. Unreported regressors include apprentice attributes (two-year age dummy variables (see appendix), French last name, Sign); other master attributes (French last name, Sign), trade dummy variables. The incidence of probation is also included as a regressor in the duration regression. The omitted categories are: Blacksmith/coachmakers, Age(14-15), and years 1791-1797. Source: ANQM.

$*, * *, * * *=$ significant at the ten, five, and one percent level (respectively).

a The sample size is smaller in the duration and probation regression because probation is uncertain in cases that did not record a 'start' date. The runaway regression includes only those contracts with a sponsor. For the incidence of rising pay, the sample refers to contracts with cash and room or board $(\mathrm{N}=1425)$

${ }^{\mathrm{b}}$ Adjusted R-squared for the OLS regression; pseudo R-squared otherwise. 